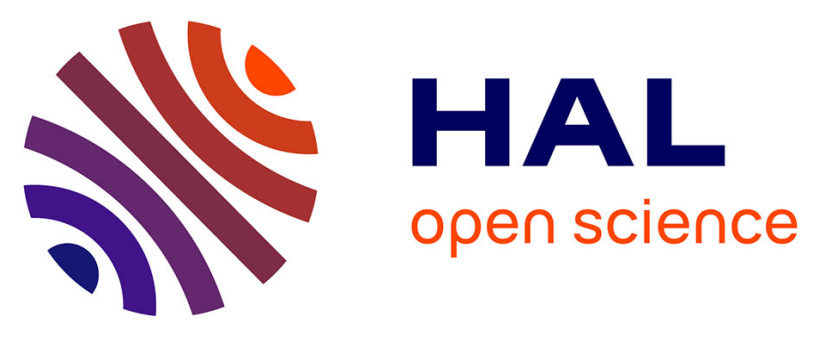

\title{
Ecology of termites from the genus Nasutitermes (Termitidae: Nasutitermitinae) and potential for science-based development of sustainable pest management programs
}

Isabelle Boulogne, Reginaldo Constantino, Nadine Amusant, Michaël

Falkowski, Alice M. S Rodrigues, Emeline S Houël

\section{To cite this version:}

Isabelle Boulogne, Reginaldo Constantino, Nadine Amusant, Michaël Falkowski, Alice M. S Rodrigues, et al.. Ecology of termites from the genus Nasutitermes (Termitidae: Nasutitermitinae) and potential for science-based development of sustainable pest management programs. Journal of Pest Science, 2017, 90 (1), pp.19 - 37. 10.1007/s10340-016-0796-x . hal-01467356

\section{HAL Id: hal-01467356 \\ https://hal.sorbonne-universite.fr/hal-01467356}

Submitted on 14 Feb 2017

HAL is a multi-disciplinary open access archive for the deposit and dissemination of scientific research documents, whether they are published or not. The documents may come from teaching and research institutions in France or abroad, or from public or private research centers.
L'archive ouverte pluridisciplinaire HAL, est destinée au dépôt et à la diffusion de documents scientifiques de niveau recherche, publiés ou non, émanant des établissements d'enseignement et de recherche français ou étrangers, des laboratoires publics ou privés.

\section{(ㄷ)(1) $\$$}

Distributed under a Creative Commons Attribution - NonCommerciall 4.0 International 
1 Ecology of termites from the genus Nasutitermes (Termitidae: Nasutitermitinae) and potential for science-based development of sustainable pest management programs

3

4 Isabelle Boulogne $\mathrm{e}^{\mathrm{a}, \mathrm{b}, \mathrm{c}^{*}}$, Reginaldo Constantino ${ }^{\mathrm{d}}$, Nadine Amusant ${ }^{\mathrm{e}}$, Michaël Falkowski ${ }^{\mathrm{b}}$, Alice 5 6 7

E-mail address: isabelle.boulogne@univ-ag.fr or isabelle.boulogne@upmc.fr

a Université des Antilles, Campus de Fouillole, 97157 Pointe-à-Pitre Cedex, Guadeloupe, FRANCE.

${ }^{\mathrm{b}}$ CNRS, UMR EcoFoG (AgroParisTech, CIRAD, INRA, UA, UG), Institut Pasteur de la Guyane, 23 Avenue Pasteur, BP6010, 97306 Cayenne Cedex, French Guiana, FRANCE.

${ }^{\mathrm{c}}$ Université Pierre et Marie Curie, UMR 7618, Institut d'Ecologie et des Sciences de l'Environnement de Paris (iEES-Paris), Département d'Ecologie Sensorielle, 75252 Paris Cedex 05, FRANCE.

d Departamento de Zoologia, Universidade de Brasília, 70910-970 Brasília, DF, BRASIL.

${ }^{\text {e }}$ CIRAD, UMR EcoFoG (AgroParisTech, CNRS, INRA, UA, UG), BP701, 97310 Kourou Cedex, French Guiana FRANCE.

${ }^{\mathrm{f}}$ Sorbonne Universités, Université Pierre et Marie Curie, CNRS, Laboratoire de Biodiversité et Biotechnologies Microbiennes (LBBM), Observatoire Océanologique, 66650 Banyuls/Mer, FRANCE.

${ }^{*}$ Corresponding author: Isabelle BOULOGNE.

Current professional adress: Université Pierre et Marie Curie, UMR 7618, Institut d'Ecologie et des Sciences de l'Environnement de Paris (iEES-Paris), Département d'Ecologie Sensorielle, 75252 Paris Cedex 05.

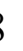




\section{Key Message}

- We reviewed the taxonomic status of Nasutitermes, which is currently the most diverse termite genus, has a particularly complex taxonomic history, and includes some major pest species.

- We performed a comparative literature analysis, especially concerning the typespecies $N$. corniger, while filtering available information concerning its biology through the prism of termite control.

- We critically examined the existing management of $N$. corniger (synthetic chemical products, botanical insecticides towards various targets, and biological control) to lead to the development of innovative management tools and strategies.

\section{Author Contribution Statement}

1 IB conceived the first draft. RC wrote the taxonomic history part and corrected biological part. EH, AR and NA corrected and greatly contributed to the pest management part. MF made all the drawings of $N$. corniger's colony. All authors read, corrected and approved the manuscript. 


\section{Abstract}

The genus Nasutitermes is among the most abundant wood-feeding Termitidae and an extremely diverse and heterogeneous group in terms of its biogeography and morphology.

Despite the major role of several Nasutitermes species as structural pests, the phylogenetic status of this genus is still unclear, alongside with a confused taxonomy and species identification remaining difficult. The first aim of this review was thus to gather and discuss studies concerning the taxonomic status of the genus Nasutitermes, in order to clarify this crucial point. Then, our goal was to gain new insights into the management of $N$. corniger, considered to be the most economically detrimental pest of this genus in South America and a Nasutitermes model species, while filtering available information concerning its biology through the prism of termite control, as well as critically examine the existing methods. We indeed strongly believe that increasing our knowledge of this species' biological strategies is the key to progress in the challenging question of their sustainable management.

62 Keywords: Taxonomic history, Nasutitermes corniger, Termitidae, sustainable management, IPM, antimicrobial and insecticidal botanical extracts. 


\section{Introduction}

The species causing the most considerable damage to tropical agriculture belong to four of the eight subfamilies of higher termites (Termitidae), and Nasutitermitinae is one of them (Rouland-Lefèvre 2011; Krishna et al. 2013). The genus Nasutitermes is among the most abundant wood-feeding Nasutitermitinae in the tropics and several Nasutitermes species are important structural pests (Constantino 2002; Fontes and Milano 2002). This genus comprises a diverse and heterogeneus group of species (Miura et al, 2000). The distributional patterns of Nasutitermes species were probably shaped by environmental conditions and historical factors, such as continental drift, orogeny, and Quaternary climatic variations (Miura et al, 2000).

As currently defined, Nasutitermes does not comprise a monophyletic group of species (Eggleton 2001; Inward et al. 2007; Roy et al. 2014), its taxonomy is confused, and accurate species identification is very difficult. Many nasute species that do not belong to the Nasutitermes clade remain nested within Nasutitermes, generating taxonomic confusion, while misidentifications and nomenclatural errors are frequent (Gush et al. 1985; Traniello et al. 1985; Constantino 2000; 2002; Scheffrahn et al. 2002; Scheffrahn et al. 2005a; Scheffrahn et al. 2005b). A comprehensive taxonomic revision of the genus is highly necessary, but has never been attempted due to the enormous difficulties involved.

However, despite this heterogeneity, some aspects, such as nest building (Thorne et al. 1996; Fuller and Postava-Davignon 2014), soldiers' defense strategies (Prestwich 1979) and hindgut microbiome role in symbiosis (Brune 2014), are well known for several Nasutitermes species. Yet, this information could be more clearly highlighted and discussed in the perspective of pest management to exploit at its most and face the growing importance of Nasutitermes pest species. These termites live in a large range of habitats in urban, anthropized, disturbed and natural environments, in dry as well as in moist conditions and at 
elevations of up to $1000 \mathrm{~m}$ (Scheffrahn et al. 2005a; Bustamante and Martius 1998; Dunn and Messier 1999, Vasconcellos and Moura 2010, Mello et al. 2014, Lima et al. 2013). This versatility, alongside with changes in urban soil occupation in the last few decades, leads to an increasing infestation in large buildings which are full of structural voids, narrow fissures and wood (Fontes and Milano 2002).

In this paper, we thus gathered and commented studies on taxonomic history and current status of genus Nasutitermes, in order to clarify this crucial point. Indeed, taxonomy provides an essential framework, as no effective and sustainable management can be set up without precisely identifying and describing the intended species.

We also aimed to gain new insights into the biology of $N$. corniger as a Nasutitermes model species, in the perspective of improving termite control. Better insights into these aspects would indeed contribute to the development of more adapted and efficient control methods, as highlighted by Scharf (2015) in a recent review.

Eventually, we critically examined the existing management methods against $N$. corniger and lastly underlined the fact that termites are also beneficial, playing a key role in the wood decomposition process.

\section{Taxonomic history of genus Nasutitermes Dudley, 1890}

Nasutitermes has a complex taxonomic history and many of the species currently included in this genus have been classified in other termite genera, while several species previously included in Nasutitermes have been transferred to other genera.

Our current taxonomic system begins with Linnaeus (1758), who described a single termite genus, Termes, which means termite in Latin. All termite species were classified in genus Termes for nearly a century after Linnaeus. In 1781 the British naturalist Henry Smeathman, described Nasutitermes arborum (as Termes arborum) from Sierra Leone, 
115 Africa, which was the first species of Nasutitermes to be formally named. Smeathman (1781)

116 also presented information on its biology, nests, and damage to houses.

Termite classification started to change in the second half of the $19^{\text {th }}$ century, when the

118 German entomologist H.A. Hagen was the main authority on termite taxonomy. Hagen's

119 (1858) monograph on world termites listed seven species of Nasutitermes, all of them

120 included in the subgenus Termes (Eutermes) Heer, 1849. Eutermes was defined based on

121 wing venation and in Hagen scheme it included a heterogeneous group of species, currently classified in several distinct genera.

The concept of "Eutermes" was restricted by Brauer (1868) to include only the termite

124 species with a nasute soldier. Müller (1873), Froggatt (1897), and Silvestri (1903) adopted

125 Brauer's definition and also raised Eutermes to the status of a genus. During that period,

126 "Eutermes" was equivalent to our current definition of the subfamily Nasutitermitinae, and included all known species of Nasutitermes.

After the discovery of many new termite species with nasute soldiers, Holmgren (1910, 1912) subdivided the genus Eutermes into several subgenera. In Holmgren's system,

130 subgenus Eutermes (Eutermes) was approximately equivalent to our current definition of 131 genus Nasutitermes.

132 The name Nasutitermes itself appears for the first time in a paper about termites of 133 Panama (Dudley 1890). Because Dudley did not provide a formal taxonomic description and

134 did not include any species in the new genus, several authors overlooked the new name. It is 135 important to note that formal international rules of nomenclature did not exist in 1890 (the

136 first edition of the Code was published in 1905). Despite its limitations, Dudley's description 137 satisfies the rules of nomenclature established in the first edition of the Code, and is therefore 138 an available name. 
Banks (1918) revealed a major problem with the previous use of the name

140 "Eutermes": its type-species, Eutermes debilis, a fossil, was identified as a species of

141 Microcerotermes, a genus with mandibulate soldiers not related to the nasutes. In the same

142 paper, Banks adopted the name Nasutitermes Dudley, 1890 for the termites with nasute

143 soldiers. The status of the name Eutermes is still considered uncertain and it has not been used

144 for living termites. However, many species currently placed in Nasutitermes appeared in the

145 literature under the name "Eutermes" for a couple of decades, including the important

146 monographs published by Holmgren $(1909,1910,1912)$.

147 The name Nasutitermes was widely adopted after 1918. Initially, it included all

148 species with nasute soldiers (= subfamily Nasutitermitinae), and was later subdivided into

149 several new subgenera and genera. Snyder's (1949) world catalog of termites lists about 400

150 species of nasute termites, classified into 25 different genera; among them, 190 species were

151 listed under the genus Nasutitermes.

Today, Nasutitermes is the most diverse termite genus, with 254 valid species

153 (Krishna et al. 2013, updated). It is present in all biogeographical regions, distributed as

154 follows: Oriental 114, Neotropical 78, Papuan 20, Ethiopian 19, Australian 19, Palearctic 14,

155 and Nearctic 01. As shown in Figure 1, new species of Nasutitermes have been discovered 156 continually since the end of the $19^{\text {th }}$ century. Variation in the description rate is related to the

157 number of active termite taxonomists, which was larger during the first half of the $20^{\text {th }}$

158 century. The total number of species is likely to increase in the future.

159 The species currently included in genus Nasutitermes do not form a monophyletic

160 group (Inward et al. 2007). Some are quite distinct from the type species (N. corniger) and

161 were included in Nasutitermes when this genus comprised most Nasutitermitinae. The

162 reexamination of the status of these species has resulted in changes in the classification, with

163 the description of new genera and reassignment of some species to other known genera of 
164 Nasutitermitinae. For instance, several species previously included in Nasutitermes were

165 transferred to Cortaritermes by Mathews (1977), Fontes (1998), and Cuezzo et al. (2015).

166 The name Nasutitermes, however, will always be associated with its type-species, $N$. 167 corniger.

\section{Nasutitermes corniger (Motschulsky, 1855) as a model species}

Nasutitermes corniger is a neotropical species which occurs natively from southern

171

172

\subsection{Biology, ecology, and behavior of Nasutitermes corniger}

\section{Apterous line: tasks and morphological polyethism}

Nasutitermes corniger is a social insect that has colonies that can contain up to 900,000 individuals (Dunn and Messier 1999; Thorne 1984). A colony is composed of workers, soldiers, and imagoes. In Termitidae, this structure originates from a common first stage of development, from which an apterous and an imaginal concurrently emerge. The imaginal line leads to the reproductive caste. From the apterous line the worker caste appears, followed by soldiers (Figure 3) (Lima et al. 2013). 
Workers are primarily responsible for foraging, constructing and repairing the nest; carrying eggs and nursing; and feeding and grooming immature stages, soldiers, and reproductives as well as participating in defensive activities with soldiers (Thorne 1984). Soldiers are a defensive caste responsible for guarding the colony (Traniello 1981; Gazal et al. 2012; Verma et al. 2009). They also organize foraging by exploring new wood sources (Traniello 1981) and by regulating foraging activity. During nest defense, soldiers squirt from their nasus a sticky, odoriferous, irritating secretion to distances of more than three times their body length (Traniello 1981; McMahan 1982). All sterile forms (workers and soldiers) are blind and lucifugous (Thorne 1983; Scheffrahn et al. 2005a; Verma et al. 2009). These termite castes are 4 to $6 \mathrm{~mm}$ long, pale and soft bodied (Figure 4); mature in one year; and can live up to 5 years (Verma et al. 2009). As is typical for the genus Nasutitermes, workers show sexual dimorphism, with females conspicuously larger than males (Lima et al. 2013; Scheffrahn et al. 2005a; Jones 1980). Soldiers represent between 5 and 20\% of a colony (Dunn and Messier 1999; Thorne 1984). They are characterized by reduced mandibles and a modified cephalic projection (the nasus), giving its name to the genus (Thorne 1984). Both soldiers and workers are completely sterile, with vestigial reproductive organs.

In a recent study, Lima et al. (2013) studied caste polymorphism of $N$. corniger apterous line using morphometric and discriminant analysis. Based on the comparison of the length of the antenna, thorax and metatibia, they highlighted two morphological types in presoldiers and soldiers, and two lines of development for workers. These elements demonstrate that morphological studies of $N$. corniger still remain crucial to increase the knowledge of the caste system in this species. Coupled with analytical and statistical tools, they can still lead to new discoveries. In addition to the rigorous determination of morphological types, these elements contribute to improving the understanding of individuals' interactions inside the colony. Lima et al. (2013) emphasized the fact that 
213 knowing whether the different morphological types perform different tasks would help in 214 understanding the behavioral dynamics in termites' societies. Former studies have, for 215 example, shown that the behavior of each caste is significantly different during nest repair and 216 nest expansion (McMahan 1970). Moreover, molecular approaches also offer promise for 217 deciphering cryptic aspects of caste biology, potentially leading to insights for new control 218 technologies (Scharf et al., 2015).

\section{Nymphal line: Description of the reproductive strategies}

Imagoes are of three types: primary reproductives (queens and kings), alates, and adultoids (Thorne 1984). They have fully developed eyes and are winged and pigmented (Scheffrahn et al. 2005a; Verma et al. 2009; Thorne 1983). The primary reproductives are the imagoes that initiated the colony after the dispersal flight. Alates are produced seasonally and leave the nest after spending 5 to 8 months within the parental colony, while adultoids are replacement reproductives derived from alates that did not disperse (Thorne 1983). line. They have two additional molts compared to worker's development. They are wingless, blind and are at the bottom of the fecundity hierarchy (Figure 3) (Thorne 1984).

Mature colonies of $N$. corniger release large numbers of alates during massive crepuscular nuptial flights $(35 \%$ of the colony biomass and 5000 to 25000 individuals on average), usually after rain (Thorne 1983). Royal couples are formed, find moist places with 233 wood food, shed their wings, and remain together throughout the life cycle of the colony. 234 Queens have a physogastric abdomen (due to ovariole growth), are capable of laying approximately 3000 eggs per day, and can live up to 25 years (Scheffrahn et al. 2005a). The eggs are yellow to white and incubate for 50 to 60 days before hatching (Verma et al. 2009). 

highest proportion of polygynous colonies, as 20 to $25 \%$ of mature colonies are headed by multiple unrelated primary reproductives (Thorne 1984; Atkinson and Adams 1997; Hartke and Rosengaus 2013). The tolerance of several queens in polygynous nests was hypothesized

241 to be due to the high individual cost of intensively laying at high rates, and this phenomenon 242 is apparently inversely related to the mean weight of queens (Adams and Atkinson 2008).

243 However, a study performed by Hartke and Rosengaus regarding the cost of pleometrosis 244 compared with colony foundation by monogamous pairs demonstrated that this strategy is 245 disadvantageous for the colony's fitness (Hartke and Rosengaus 2013). Thus, mature 246 polygamous nests of $N$. corniger may not be established via pleometrosis, but may imply 247 other phenomena, such as the coalescence of young monogamous colonies. In fact, polygyny 248 in N. corniger, as in the case of other Isoptera and some Hymenoptera, is not accompanied by 249 nepotism because no data showed that workers care for their mothers more than the other 250 queens (Atkinson et al. 2008). Likewise, experimental young colonies easily merged under 251 laboratory conditions (Hartke and Rosengaus 2013). These results highlight the fact that 252 further studies may be useful to understand the exact process as well as the ecological 253 advantages of this phenomenon of colony fusion. Alongside its feeding habits and the aspects 254 related to nesting, these reproduction mechanisms may play a part in the species' success in 255 colonizing space, thus making $N$. corniger a major urban pest (Mello et al. 2014).

\section{Role of the nest: from structural protection to immunity enhancement}

258 Nests of $N$. corniger (Figure 5) are constructed on trees, bases of trunks, in secluded 259 places of buildings or, less often, on the open soil (Scheffrahn et al. 2005a). These nests are 260 single or polycalic, from ovoid to conical in form, with dimensions ranging up to $90 \mathrm{~cm}$ in 261 height and $40 \mathrm{~cm}$ in width (Dunn and Messier 1999; McMahan 1982; Levings and Adams 
1984; Scheffrahn et al. 1990). The nests have three parts: a superficial area with a thin skin of 263 carton, which can exclude predators and prevent desiccation and flooding conditions 264 (McMahan 1982; Fuller and Postava-Davignon, 2014); a middle part consisting of 265 interconnecting galleries and chambers made of hard and dense carton (McMahan 1982); and 266 a queen chamber located near the center of the nest (Thorne 1980). Additionally, carton267 covered tunnels radiate from the nest and provide protection to termites during foraging 268 (Levings and Adams 1984). This particular organization represents a challenge in termite management, because nests are often distant from infestation sites and are so structurally sound, Nasutitermes control can thus often be difficult (Fontes and Milano 2002; Gazal et al. 2012).

The stercoral carton used by termite workers during foraging, constructing or repairing processes is a black substance mainly composed of masticated wood and feces, cemented with salivary secretions (Postava-Davignon 2010; Traniello 1981; McMahan 1982). In addition, some other chemical or biological substances can also be incorporated inside this material. For example, $\beta(1,3)$-glucanase activity was recently discovered in the $N$. corniger nest carton 277 due to the presence of the native tGNBP-2 protein. By cleaving and releasing pathogenic 278 components, it participates in the colony's immunological defense system against infections 279 (Bulmer et al. 2004; 2009). Also, preliminary results obtained on N. acajutlae highlighted that, in general, fewer bacteria and fungi were observed inside the nests compared to the soil and trails (Postava-Davignon 2010). Thus, Nasutitermes nests are effective structures that 282 allow the insects to survive in their environment, and antimicrobial defense integrated in the 283 structure can help termites to enhance their immunity. This perfectly exemplifies the richness 284 of defense strategies among insect colonies. Based on this information, Bulmer et al. (2009) 285 developed a glycomimetic molecule blocking tGNBP-2 using rational design, which increases 286 infection and death rate of exposed termites and can be used as an alternative control method. 
This work clearly demonstrated that understanding termite biology is key to their sustainable management, as well as the resolution of product engineering and development issues.

\section{Pheromone biology: communication, recruitment, modulation}

Chemical odor trails are produced by the sternal gland (Stuart 1963). This gland is located on the fifth abdominal sternite and is composed of modified epidermal cells (Traniello and Busher 1985). Soldiers' sternal glands are smaller, on average, than workers'. These sternal pheromones are implicated in several aspects of the colony life. When nest defense is necessary, soldiers release a secretion from their nasus, which contains a mixture of terpenoids and elicits alarm and defensive recruitment (Thorne 1984; Roisin et al. 1990). Pheromones also communicate information about the presence and location of food, are used to recruit more soldiers and workers, and can modulate caste differentiation, either positively or negatively (Traniello and Busher 1985; Scharf 2015).

Recruitment was formerly proposed to depend on the quantitative production of the pheromone (Traniello and Busher 1985). In fact, it was effectively measured that the worker/soldier concentration ratio was 0.2 times for compounds concentrated in $N$. corniger (Arab et al. 2006). Moreover, behavioral evidence for species, colony, and caste specificity of the trail pheromone were also presented (Dunn and Messier 1999; Arab et al. 2006). In particular, Arab et al. (2006) described that both $N$. corniger workers and soldiers preferred the trails made by conspecific soldiers over those from workers. Extracts from the same species, and more particularly from the same colony, were also demonstrated to be preferred (Arab et al. 2006). Dunn and Messier (1999) highlighted that soldiers are able to discriminate their own colony members from conspecific neighbors and strangers; therefore, they behave more aggressively toward neighbors, with which they are competing for resources and territory, compared to strangers. 
If quantitative differences between soldiers' and workers' trail pheromones can help to regulate the foraging behavior of these termites, the chemical composition of the sternal gland secretions should also be taken into account. For example, chemical analysis identified neocembrene, dodecatrienol and trinervitatriene in the pheromone trail, with a ratio of

316 dodecatrienol/neocembrene of 1:25 and a ratio of trinervitatriene/neocembrene of 1:2 in the

317 sternal glands of N. corniger's workers (Sillam-Dussès et al. 2010). Monocyclic 14-membered

318 ring diterpene cembrene-A is also a common constituent of this trail and is a short-term alarm 319 capable of orienting soldiers to an area of disturbance (Hall and Traniello 1985). Moreover, 320 some other parameters may play an important role in trail following. For example, a study 321 performed by Gazal et al. highlighted the significant effect of feces on the trail (Gazal et al. 322 2014). Chemical analyses on the feces' composition, and behavioral studies implicating the 323 identified compounds, may lead to valuable information that could help to improve the 324 understanding of trail following mechanisms. This could be of importance to develop 325 attractant or repulsive products in the context of an integrated pest management procedure. In 326 addition to their crucial role for recruitment, chemical trails also probably exhibit 327 antimicrobial activities and might be involved in the control of nest microbial competitors 328 (Rosengaus et al. 2000). According to these results, studying the influence of the 329 morphological type on potential specificity induction in trail preference could also lead to 330 interesting results, besides contributing to the understanding of the social function of each 331 morphological type inside a colony. Eventually, as primer pheromones from soldiers and 332 other castes may also regulate caste homeostasis (Scharf et al., 2015), studying these 333 compounds and their associated biology could potentially lead to insights for new control 334 technologies.

\section{Food selection: a complex process}



2013). It has the ability to consume a large variety of wood, such as dead twigs and branches in trees, tree stumps, wood debris on the ground and structural wood, including framing,

340 plywood, pressboard, hardwood handles, wooden artwork, fences and paper and derivatives in 341 laboratory conditions (Scheffrahn et al. 2005a). However, the exact stimuli implicated in the 342 finding and selection of food by $N$. corniger is still under evaluation. Nasutitermes corniger was first described as having no significant consumption 344 preference among different wood species, but with a strong preference for decayed over fresh 345 wood (Bustamante and Martius 1998). However, further contradictory studies demonstrated a 346 significant species preference under laboratory conditions (Gazal et al. 2010). Yet, consistent 347 with the results obtained by Bustamante and Martius (1998), the choice was not shown to 348 exclusively depend on the density. Concerning the stage of decay of the wood, a more recent 349 study conducted by Gazal et al. (2012) confirmed the results of Bustamante and Martius. 350 Whatever the tested species, decayed wood always recruited more individuals than undecayed 351 wood in standard foraging arenas. The next step was to investigate whether the choice of the 352 source of wood was attributed to physical or chemical factors. This work thus demonstrated 353 the crucial role of the secondary metabolites produced during wood degradation in the choice 354 of a food substrate by comparing impregnation of a neutral (filter paper) and of wood (fresh 355 or decayed) substrate with weathered or unweathered Eucalyptus grandis wood extracts 356 (Gazal et al. 2014).

357 Following these results, further studies should be performed on the identification and 358 origin of the compounds linked to wood degradation and to investigate their action on wood's 359 physicochemical properties. It may also be interesting to investigate the effect of weathered 360 and unweathered extracts on a neutral wood substrate from which secondary metabolites 361 would have been removed or on non-durable wood, such as Pinus sp. According to some 
authors, the preference for decayed wood could be due to several factors. Decomposition may

363 lead to an increase of nutrient availability and a facilitation of mastication during the process

364 and the depolymerization of cellulose, making wood fibers easier to remove and compounds

365 more degradable. Moreover, it is possible that wood degradation releases allelochemicals that

366 influence the foraging behavior or trigger trail following. Decomposition is also associated

367 with the presence of microorganisms, notably fungi, which are potential additional sources of

368 nitrogen and vitamins for the termites (Vasconcellos and Moura 2010; Gazal et al. 2012;

369 Gazal et al. 2014). In addition to improve the ecological and biological knowledge of the

370 species, understanding the mechanisms of termites' food selection would play a central role in

371 developing new techniques to control N. corniger in case of infestation, such as substrates for

372 insecticide-impregnated baits, or prevent $N$. corniger colonization of buildings by orienting 373 technological choices.

\section{Symbiosis and mutualism}

The insect gut is divided into three regions: the stomodeum (foregut), the mesenteron

377 (midgut), and the proctodeum (hindgut). The foregut includes the crop, a food-storage organ.

378 In termites, the hindgut is enlarged and subdivided into five segments (P1-P5). The crop is 379 slightly acidic, whereas the hindgut is moderately alkaline, with anaerobic conditions (Bignell 380 and Anderson 1980). In the third hindgut segment (P3 or paunch), a bacterial community has 381 developed that confers certain important benefits to the termite. In fact, in the case of $N$. 382 corniger, such as other higher termites (Termitidae), digestive enzymes are encoded both by 383 the termite genome itself and by these symbiotic bacteria, as these species do not possess 384 hindgut flagellate protozoa, contrary to lower termites for which these organisms are the 385 sources of cellulases and hemicellulases (Warnecke et al. 2007). However, this microbiome 386 appears to play a far more complex role than only being related to cellulose degradation, as in 
nitrogen fixation (Prestwich and Bentley 1981; Tayasu et al. 1994). In the case of an arboreal species close to $N$. corniger, a metagenomic analysis of the hindgut-associated microbial community highlighted the presence of bacterial genes for cellulose and xylan hydrolysis and also provided information about the possible functional role of this community concerning

391 free $\mathrm{H}_{2}$ generation and $\mathrm{CO}_{2}$-reductive acetogenesis, alongside the identification of genes 392 associated with nitrogen fixation (Warnecke et al. 2007). Metaproteome analysis of this 393 community revealed the presence of proteins of known enzymatic functions in the case of $N$. corniger, thus permitting the reconstruction of the enzymatic pathways concerning transport, 395 glucan binding, sugar fermentation, hydrogen metabolism, amino acid synthesis, and nitrogen 396 fixation and assimilation (Burnum et al. 2010). These findings are complementary to the 397 results previously obtained by Warnecke et al. (2007), although from all the isolated known 398 proteins no enzyme involved in cellulose degradation could be observed. This may be due to 399 methodic limitations, or because the cellulose native degradation may occur elsewhere than 400 inside the termite hindgut. Spirochetes, mostly from the Treponema genus, and Fibrobacteres, alongside an 402 undetermined phylum (TG3), were the most abundant phyla of these $N$. corniger microbial 403 symbionts and were established to be fiber-associated bacterial communities that significantly 404 contribute to the cellulotic activity (He et al. 2013; Warnecke et al. 2007; Mikaelyan et al. 405 2014). Warnecke et al. (2007) also demonstrated that gene modules coding for iron-only 406 hydrogenase were bound to the genus Treponema, as well as maker genes linked to the 407 acetogenesis pathway, and this process apparently dominates in Nasutitermes by 408 Spirochaetes. In the actinobacterial community, well known for its role in organic matter 409 decomposition, such as cellulose, five families (Propionibacteriaceae, Streptomycetaceae, 410 Cellulomonodaceae, Corynebacteriaceae and Rubrobacteraceae) were identified for $N$. 411 corniger, regardless of the geographical origin or feeding behavior (Lefebvre et al. 2009). 
Regarding the apparent role of microbial symbionts concerning cellulose digestion and

413 other essential metabolic functions, disrupting this effective equilibrium would be important

414 in the continuous search for insecticidal products. In fact, it was demonstrated that modifying

415 the carbon source allocated to the higher termite $N$. takasagoenis led to marked changes in the

416 bacterial community structure, thus highlighting the delicateness of this relationship (Miyata

417 et al. 2007). Moreover, in the case of an integrated pest management strategy, searching for

418 products that exhibit antimicrobial activity seems to be a promising perspective (Shelton and

419 Grace 2003).

420 Concurrent to this crucial symbiosis, other types of associations can be observed in

421 termites' societies. In particular, ants could be associated with facultative or opportunistic

422 mutualism where these insects use part of the termite nest, prey on live or dead workers,

423 provide the termites with nitrogen nutrients and assist in nest protection. The frequency of $N$.

424 corniger association with ant species depends, in particular, on the cost-benefit balance linked

425 to predation risk. A Brazilian study demonstrated that Formicidae species richness in

426 Nasutitermes' nests ( $N$. corniger and N. ephratae) was significantly higher in abandoned

427 nests, in 48 species, compared to active or decadent nests, in 6 and 8 species (Santos et al.

428 2010). In the latter case, Crematogaster acuta (Fabricius) and Ectatomma tuberculatum

429 (Olivier) were the most frequent species observed. Monacis bispinosa (Olivier), which is

430 highly susceptible to the soldier frontal gland mixture and which do not prey on live termites,

431 was the most frequently found species in common ants / $N$. corniger nests in Venezuela (Jaffe

432 et al. 1995). Crematogaster brevispinosa (Mayr), an arboreal ant, has been observed in

433 association with $N$. corniger in Brazil, sharing the same nest even if a physical barrier is built

434 between the two communities. The participation of ants in nest protection and nutritional

435 substrate supply thus appears to be another factor contributing to the success of $N$. corniger

436 colonization. 


\subsection{Pest management}

439 Synthetic chemical products, as active substances inhibiting wood degradation by termites 440 and microorganisms, can be applied through soil, wood treatment, or chemical fumigations, 441 before or after infestation (Paiva et al. 2011) (Table 1). Excellent reviews or technical reports, 442 such as those by Schultz et al. $(2007 ; 2008)$ concerning wood preservation, Verma et al. 443 (2009) on the biological control of termites, or the expert group on termite biology and 444 management of the United Nations Environment Program (UNEP 2000), have taken an 445 inventory of the different strategies, depending on the geographical zone. Despite the 446 perceived efficiency of all of these substances, we cannot ignore the constraints on use, 447 environmental risk, human health and toxicity to non-target organisms (Pluke et al. 1999; 448 Clausen and Yang 2007; Santana et al. 2010; Scheffrahn and Scherer 2013; Scheffrahn et al. 449 2014). However, the efficacy of the different strategies mentioned above is mainly evaluated 450 against subterranean termite species. Despite their recognized status as a significant urban 451 pest, few references specifically mention arboreal termites, particularly Nasutitermes spp. 452 This observation can be explained by several factors. First, damages caused by subterranean 453 termites are less predictable, and preventive treatments must therefore be very efficient and 454 are crucially needed. In fact, in regard to physical management, the easily detected $N$. corniger nests are often simply collected, broken and/or burnt (UNEP 2000; Pluke et al. 456 1999), whereas barriers often containing insecticides must be used as a management strategy 457 for subterranean termites (Verma et al. 2009; UNEP 2000; Paiva et al. 2011). A second factor 458 to be taken into account is the fact that Nasutitermes species mostly impact Central and South 459 America, alongside other tropical zones of the globe, such as Southeast Asia and Australia, 460 while the main commercial markets related to insecticidal products are located in the 461 Northern hemisphere, mostly concerned with subterranean termites (Constantino et al. 2002; 
462 UNEP 2000; Miura et al. 2000). For example, in 2008, North America represented 60\% of

463 the total market for wood preserving biocides and Europe and Asia/Oceania represented 20\% 464 each (Schultz et al. 2008).

However, products for wood protection commercially available in the market must be active against a wide range of organisms, from decaying fungi to various xylophagous insects

467 (Schultz et al. 2007). Even if species specificities exist, the insecticidal products mainly tested 468 on subterranean termites (which target the workers caste) are thus also efficient towards arboreal termites, such as $N$. corniger. In the following sections, we thus focused as much as possible on environmentally low-risk management strategies, presenting examples specifically concerning $N$. corniger but also some references concerning Nasutitermes sp. and 472 sometimes about other termites species when needed.

\section{Botanical insecticides: antitermitic extracts and compounds}

Numerous laboratory studies target the evaluation of botanical extracts and natural compounds against termites. Even if they mostly address the activity of these products against

477 subterranean species, some interesting results can be cited concerning Nasutitermes spp. and, 478 more particularly N. corniger.

One strategy for finding new specific termiticidal compounds from botanical sources is called "bioinspiration," which aims to understand the functional role of secondary 481 metabolites in living organisms, thus gaining inspiration from the abilities of plants or 482 microorganisms to produce adapted bioactive molecules under specific environmental 483 conditions (Rodrigues et al. 2010; Basset et al. 2012; Houël et al. 2015). In particular, one 484 source for these antitermitic natural compounds are woods naturally resistant to 485 biodegradation, which is closely linked to the accumulation of extractives typically in the 486 heartwood (Taylor et al. 2002; Ragon et al. 2008; Kampe and Magel 2013). Results 
concerning wood extracts activity against N. corniger or Nasutitermes sp. (Peres Filho et al. 2006; Barbosa et al. 2007; Sá et al. 2008; 2009; Santana et al. 2010; Boulogne et al. 2011; Rodrigues et al. 2011; Rodrigues et al. 2010) are summed up in Table 2.

The research for natural extracts for wood protection contemplates various modes of action such as elicitors, regulators, inhibitors, enzymes, or repellents for pest control. In fact, specific defense mechanisms were evidenced in plant seeds and roots, which are essential for the propagation and survival of the species. Lectins, for example, which are toxic proteins widely distributed among plants, are supposedly involved in defense mechanisms against phytophagous predators (Carlini and Grossi 2002). These compounds, isolated from various sources, were extensively studied for their insecticidal activity, $N$. corniger being among the selected targets (Sá et al. 2008; Silva et al. 2009; Napoleão et al. 2011; Paiva et al. 2011; Souza et al. 2011). These proteins play a role in cell agglutination by carbohydrate recognition and could therefore act by binding to glycoproteins present in the insect's digestive tract (Sá et al. 2008). They were demonstrated to be able to disrupt enzymes' activities from the gut of termites (Lima et al. 2014). These molecules are now the basis of commercial formulations currently developed against termites (Paiva et al. 2011). Eventually, some well-known insecticidal compounds from plant extracts are active as biocides, strong repellants or antifeedants against several species, including subterranean termites (Sharma et al. 1991; Grace and Yates 1992; Serit et al. 1992; Ivbijaro 1993; Delate and Grace 1995; Chuanchuan et al. 1998; UNEP 2000; YunLing et al. 2009; Tahiri et al. 2011; Sharma et al. 2011; Himmi et al. 2013; Boulogne et al. In prep.) (Table 2).

Concurrently to the evaluation of extracts' biological activity, several reviews have been reported in natural products for wood protection (Singh and Singh 2012; Verma et al. 2009; Yang 2009; Mai et al. 2004; Kirker et al. 2013; González-Laredo et al. 2015). These reports discuss the development of botanical pesticides against subterranean termites, with in 
512 particular results concerning Nasutitermes wood decay control. Some extracts could be 513 employed unadjuvanted as wood protectants, as reported in an African study, about the 514 effective extracts of Erythrophleum suaveolens (Guill. \& Perr.) Brenan (Fabaceae), 515 Azadirachta indica A. Juss. (Meliaceae) and Chromolaena odorata (L.) King \& Rob. 516 (Asteraceae) in improving the durability of Antiaris toxicaria Lesch. (Moraceae) wood, 517 exposed to decay for five years (Antwi-Boasiako and Damoah, 2010). In another study, 518 Cryptomeria japonica (Thunb. ex L. f.) D. Don (Cupressaceae) wood treated with essential 519 oils, showed strong activity against subterranean termites, in a three weeks test (Kartal et al., 520 2006). Turner and Conradie have also demonstrated the enhanced termitic resistance of Pinus 521 patula Schltdl. \& Cham. (Pinaceae) treated with extracts from four African durable species 522 Breonadia salicina (Vahl) Hepper \& Wood (Rubiaceae), Spirostachys Africana Sond. 523 (Euphorbiaceae), Ptaeroxylon obliquum (Thunb.) Radlk. (Rutaceae) and Syncarpia 524 glomulifera (Sm.) Nied. (Myrtaceae)- in a two years test (Turner and Conradie, 1995).

Another way to employ botanical pesticides is to combine natural products to other protectants compounds, such as described in a 2007 study, where 0.5 percent thujaplicin was

527 used in several multicomponent biocide systems with borate and carbon-based biocides. 528 Noticeable results were obtained for protecting wood from mold, decay, and termite damage 529 (Clausen and Yang 2007).

Despite all these advances, until now there has been no available chemical formulation

531 containing these compounds for wood treatment against termites. Moreover, although they 532 present a repulsive effect against $N$. corniger, their effects are not persistent and they did not 533 lead to any contact toxicity (Paes et al. 2010).

\section{Botanical insecticides: antimicrobial extracts and compounds}



insect as a target, thus highlighting potent extracts or molecules. However, another process could be used to precisely search for compounds or extracts acting on a selected mechanism of action, as exemplified by Bulmer et al. (2009) with the glycomimetic molecule D- $\delta$ 540 gluconolactone, as above cited in this review. Thus, in-depth studies of N. corniger biology 541 could be helpful for the discovery of targeted alternatives to non-specific pesticides. Another specific approach based on natural processes is searching for phytochemicals 543 targeting termites bacterial gut community. Even if some publications describe antimicrobial 544 activities of compounds isolated from Nasutitermes sp. (Zhao et al. 2004; Siderhurst et al. 545 2005; Coutinho et al. 2009; Coutinho et al. 2010; Nirma et al. 2013), few articles describe the 546 search for antibacterial products according to the perspective of an integrated pest 547 management strategy against Nasutitermes species. However, a recent study showed that 548 botanical lectins had an antibacterial effect on symbiotic bacteria from the gut of N. corniger 549 (Napoleão et al. 2011). This approach could be of valuable interest, as similar results have 550 also been achieved with other termite species (Table 2) (Maistrello et al. 2001; Maistrello et 551 al. 2003; Ahmed et al. 2006; Doolittle et al. 2007).

\section{Other biopesticides}

Other strategy for finding new termiticidal compounds from other sources is considering soil actinomycetes fermentation products. These naturally occurring compounds

556 were discovered from Streptomyces sp. culture broths. Some studies dealt with control of 557 termites with these pesticides. Indeed, Chen et al. (2015) found that avermectin (abamectin 558 and ivermectin) has optimal insecticidal properties to manage the subterranean termite 559 Reticulitermes speratus. This strategy could be tested in the control of Nasutitermes but it has 560 to be taken into account that these compounds have a large range of action and thus 
potentially noticeable impact in the field, being used in particular as an agent against worms,

562 ticks, flies and other insects in veterinary applications (Duke et al. 2010).

\section{Biological control of termites: entomopathogens and natural enemies}

Nematodes, bacteria, and fungi have several interesting properties for the biological control of termites (Verma et al. 2009; Paiva et al. 2011). In recent years, the number of publications concerning the biological control of termites has increased dramatically (Chouvenc et al. 2011). In a critical review based on the study of 227 publications in which 427 bioassays were reported, Chouvenc et al. (2011) showed that these strategies were largely unsuccessful. Even if numerous examples of bacterial and nematode control can be found in

571 the recent literature, mostly concerning subterranean termites (Grewal et al. 1999; Mo et al.

572 2006; Devi et al. 2007; Verma et al. 2009; Chouvenc et al. 2011), the authors raise questions 573 about the fact that the described protocols may encounter poor biological relevancy, that the 574 obtained data may often be improperly and overly optimistically interpreted, and that field 575 bioassays often lack (Chouvenc et al. 2011). Other reasons that potentially explain this 576 lacking of success may be linked to the remarkable way that termites have evolved to resist 577 diseases due to biochemical and immunological strategies (Meikle et al. 2005), as also exemplified earlier in this review.

Among the few successes, biological control using fungi against Nasutitermes sp.

580 (Table 2) should be mentioned (Ensaf et al. 2006; Chouvenc et al. 2011; Salas-Acuña 2012).

581 A commercial formulation using the generalist enthomopathogenic fungus Metarhizium 582 anisopliae (formerly flavoviride) (Metsch.) Sorokin (Bioblast ${ }^{\mathrm{TM}}$, Ecoscience Co.) was 583 developed, but was unfortunately removed from the market in the early 2000 s due to 584 insufficient results (Verma et al. 2009; Chouvenc et al. 2011). The pathogenicity of the 585 fungus is dependent on various factors, such as its capacity for germination and penetration 
on and through the cuticle as well as the insect's immune system to prevent fungus growth

587 (Verma et al. 2009). A perspective to improve the efficacy of this enthomopathogen would therefore be to collect strains directly from native infected termites to improve the probability of isolating fungi having circumvented termites' adaptation strategies and natural defenses

590 (Meikle et al. 2005). The challenge in termites' biological control is thus to develop more 591 biologically relevant models, promote interdisciplinarity to finalize and conduct the assays, 592 and add field and technology transfer studies (Chouvenc et al. 2011). As described earlier in their review, Chouvenc et al. (2011) also clearly appeal to an increase in research concerning termites' biology to find ways for pathogens to bypass termites' defense mechanisms. predators like ants, such as Camponotus abdominalis, one of the most aggressive species of this fierce natural enemy of termites (UNEP 2000). Another well-known predator of $N$. corniger is the hemipteran Salyavata variegata nymph (Reduviidae), which captures termite workers with the help of traps made of empty carcasses of previous prey and carton crumbs (McMahan 1982). However, the investigation of natural predators as control agents did not reveal any commercial potential (Chouvenc et al. 2011).

602

603

\subsection{Not only a pest!}

604

As with other termite species, $N$. corniger is a decomposer insect that plays a 605 fundamental role in the decomposition process and nutrient cycling by aerating the soil, 606 recycling plant matter and fixing nitrogen (Vasconcellos and Moura 2010). The presence of 607 these insects also indicates the good health of an ecosystem, and they can be considered as 608 bioindicators of its actual function (Täyasu et al. 1994; Paiva et al. 2011). Moreover, the 609 presence of termites has a positive impact on biodiversity, termitariophile organisms, or 610 insects depending on the nest structure for shelter, food or reproduction, thus being 
611 maintained in the environment (Jaffe et al. 1995; Santos et al. 2010). Eventually, arboreal

612 nests may also provide homes for other animals, such as birds and bats (Postava-Davignon et 613 al. 2010).

614 Concurrently with playing a role in dynamic environmental processes, $N$. corniger can 615 also provide services to mankind, acting as a source of active secondary metabolites, 616 particularly antimicrobial compounds. Inspired from its traditional use as a medicine in 617 Northeastern Brazil, aqueous extracts from $N$. corniger were studied and shown to exhibit low 618 antimicrobial activity against Escherichia coli aminoglycoside-resistant strains, but presented 619 interesting synergist activities with antibiotics (Coutinho et al. 2009; 2010). Extracts from $N$. 620 corniger could therefore be used as sources of compounds to bypass bacterial resistance 621 mechanisms. Other results highlighted antibacterial (Zhao et al. 2004) or antifungal (Bulmer 622 and Crozier 2004) activities for compounds isolated from Nasutitermes species. Eventually, active compounds can also be obtained through termites' symbionts, such as the antifungal compounds tyroscherin and N-methyltyroscherin, isolated from Pseudallescheria boydii, a saprophytic fungus frequently found in soil and water, but that was isolated in this case from 626 Nasutitermes sp. (Nirma et al. 2013). In addition to appealing to the preservation and the 627 pharmacochemical study of this species, these examples highlight the fact that improving the 628 knowledge of termites, and more particularly $N$. corniger biology, could lead to a marked 629 improvement, not only in the pest management field but also in the continuous search for new 630 antimicrobial compounds.

\section{Conclusion}

Nasutitermes is the most species-rich termite genus, with a complex taxonomic

634 history, and a growing number of known species present in all biogeographical regions. 635 Nasutitermes corniger, which is the type-species of the genus, is an urban and agricultural 
pest, and also an invasive species, with a remarkable ability to adapt to a variety of habitats

637 and food sources. Controversially, ecological and human health problems potentially arising

638 from the use of synthetic chemical substances, particularly if the label guidelines are not

639 strictly followed, are the limiting factor for their use. However, the extensive use of botanical

640 or biological insecticides remains up to date unconclusive because of their ineffectiveness or

641 their poor durability in external wood exposure cases. In the continuous effort to develop safe

642 and effective methods for conehead termite management, we therefore believe that a

643 paradigm shift is necessary and that sustained efforts must be performed in the field of termite

644 biology. Alongside an increase in field bioassays, improvement in this knowledge is the key

645 to more elaborate pertinent models and integrated strategies, targeting both the insect and its

646 symbionts.

647 Eventually, integrated management rather than eradication is necessary in the native 648 zones of occurrence of this termite. Although it is considered to be a pest, the termite is 649 clearly an essential component of ecosystems as well as a potential source of valuable 650 compounds that could contribute to the improvement of human health. Thus, the perspective 651 remains open concerning Nasutitermes species study and management, and exciting 652 discoveries are still to be made.

\section{Acknowledgements}

655 The authors gratefully thank Dr. Philippe Petit (French West Indies University, UA) 656 for providing Lonchocarpus sp. vegetal material, and Arnaud Jahn-Oyac for his technical 657 help. The authors also wish to thank Dr. Thomas Chouvenc from University of Florida for 658 identifying $N$. corniger from our field collections. This work is part of the INSECTICIDES 659 project funded by Europe (ERDF OP), French Guiana Regional Council and the Air Liquide 
660 Foundation. This work benefited from an "Investissement d'Avenir" grant managed by

661 Agence Nationale de la Recherche (CEBA, ref. ANR-10-LABX-25-01).

662

\section{References}

664

Adams E, Atkinson L (2008) Queen fecundity and reproductive skew in the termite Nasutitermes corniger. Insect Soc 55:28-36

667

Ahmed S, Riaz MA, Shahid M (2006) Response of Microtermes obesi (Isoptera: Termitidae) and its gut bacteria towards some plant extracts. J Food Agric Environ $4: 317-320$

671

Arab A, Issa S, Alfonzo D, Jaffe K (2006) Caste, colony, and species specificity of the trail pheromone in two sympatric Nasutitermitinae (Isoptera: Termitidae). Sociobiology 47:345-351

675

Atkinson L, Adams ES (1997) The origins and relatedness of multiple reproductives in colonies of the termite Nasutitermes corniger. P Roy Soc Lond B Bio 264:1131-1136

678

Atkinson L, Teschendorf G, Adams ES (2008) Lack of evidence for nepotism by workers tending queens of the polygynous termite Nasutitermes corniger. Behav Ecol Sociobiol 62:805-812

682 
686 Barbosa AP, Nascimento CS, Morais JW (2007) Studies on the antitermitic properties of wood and bark crude extracts of forest species from Central Amazonian, Brazil. Acta Amazonica 37:213-218

689

Basset C, Rodrigues AMS, Eparvier V, Silva MRR, Lopes NP, Sabati $\neg$ r D, Fonty E, Espindola LS, Stien D (2012) Secondary metabolites from Spirotropis longifolia (DC) Baill and their antifungal activity against human pathogenic fungi. Phytochemistry 74: 166-172.

694

Bignell D, Anderson J (1980) Determination of $\mathrm{pH}$ and oxygen status in the guts of lower and higher termites. J Insect Physiol 26:183-188

697

Boulogne I, Germosen-Robineau L, Ozier-Lafontaine H, Jacoby-Koaly C, Aurela L, 699 Loranger-Merciris G (2011) Acromyrmex octospinosus (Hymenoptera: Formicidae) management. Part1. Effects of TRAMILs insecticidal plant extracts. Pest Manage Sci 68:313-320

702 Investigating a strong difference of insecticidal activity and cytotoxicity between two thinly known ichthyotoxic species: Lonchocarpus chrysophyllus Kleinhoonte and Lonchocarpus floribundus Benth Verhandlungen der ZoologischBotanischen Gesellschaft in Wien 18: 359-416 
711 Brune A (2014) Symbiotic digestion of lignocellulose in termite guts. Nat Rev Microbiol $12: 168-180$

Bulmer M S, Crozier RH (2004) Duplication and diversifying selection among termite antifungal peptides. Mol Biol Evol 21:2256-2264

Bulmer MS, Bachelet I, Raman R, Rosengaus RB, Sasisekharan R (2009) Targeting an antimicrobial effector function in insect immunity as a pest control strategy. P Roy Soc Lond B Bio 106:12652-12657 RH, Smith RD, Lipton MS (2010) Proteome insights into the symbiotic relationship between a captive colony of Nasutitermes corniger and its hindgut microbiome. ISME J 5:161-164

Bustamante NC and Martius C (1998) Nutritional attractiveness of wood-feeding termites inhabiting floodplain forest of the Amazon river, Brazil. Acta Amazonica 28:301-307

Carlini C, Grossi-de-Sa MF (2002) Plant toxic proteins with insecticidal properties. A review on their potentialities as bioinsecticides. Toxicon 40:1515-1539 mediated effects of ten insecticides on the subterranean termite Reticulitermes speratus. J Pest Sci 88:741-751 
736 Chouvenc T, Su N-Y, Kenneth Grace J (2011) Fifty years of attempted biological control of termites - Analysis of a failure. Biol Control 59:69-82

Chuanchuan L, Rongjing X, Haoquan Z, Keng C (1998) The effects of a Neem insecticide on orientation and feeding behaviour of Coptotermes formosanus (Isoptera:Rhinotermitidae).http://en.cnki.com.cn/Article_en/CJFDTOTALBYKJ19980 1001.htm

Clausen CA, Yang V (2007) Protecting wood from mould, decay, and termites with multi-component biocide systems. Int Biodeter Biodegr 59:20-24

Constantino R (2002) The pest termites of South America: taxonomy, distribution and status. J Appl Entomol 126:355-365

Constantino R (2000) Online termite database. Departamento de Zoologia, Universidade de Brasília. http://www.unb.br/ib/zoo/docente/constant/catal/catnew.html Filho GG (2010) Natural products from the termite Nasutitermes corniger lowers aminoglycoside minimum inhibitory concentrations. Pharmacogn Mag 6:1-4 
antibiotic activity by natural products of Nasutitermes corniger (Motschulsky 1855). BMC Complem Altern M 9:35 Dudley to Cortaritermes Mathews (Isoptera: Termitidae: Nasutitermitinae). Austral Entomol 54: 172-179

765

Delate KM, Grace JK (1995) Susceptibility of neem to attack by the Formosan subterranean termite, Coptotermes formosanus Shir. (Isopt., Rhinotermitidae). J Appl Entomol 119:93-95

Devi KK, Seth N, Kothamasi S, Kothamasi D (2007) Hydrogen cyanide-producing rhizobacteria kill subterranean termite Odontotermes obesus (rambur) by cyanide poisoning under in vitro conditions. Curr Microbiol 54:74-78

Doolittle M, Raina A, Lax A, Boopathy R (2007) Effect of natural products on gut microbes in Formosan subterranean termite, Coptotermes formosanus. Int Biodeter Biodegr 59:69-71 in termites. J Insect Behav 12:461-464 
Eggleton P (2001) Termites and trees: a review of recent advances in termite phylogenetics. Insect Soc 48:187-193

Ensaf A, Bouree P, Callard P (2006) Potentialités de Termitaria coronata thaxter, 1920 (Deutéromycètes, Termitariales) pour la lutte biologique contre les termites (Isoptera). Bulletin de la Société entomologique de France 111:43-49

Evans TA, Forschler BT, Grace JK (2013) Biology of invasive termites: a worldwide review. Ann Rev Entomol 58:455-474

796

Fontes LR (1998) Novos aditamentos ao "Catálogo dos Isoptera do Novo Mundo", e uma filogenia para os gêneros neotropicais de Nasutitermitinae. In: L.R. Fontes \& E. BertiFilho, Eds. Cupins: O desafio do conhecimento. FEALQ, Piracicaba, pp. 309-412

800

801

Fontes LR, Milano S (2002) Termites as an urban problem in South America.

802 Sociobiology 40:103-151

803

804 Froggatt WW (1897) Australian termites. Part II. P Linn Soc N S W 21:510-552

805

806 Fuller CA, Postava-Davignon M (2014) Termites like it hot and humid: the abity of 807 arboreal tropical termites to mediate their nest environment against ambient conditions. Ecol Entomol 39:253-262 
810 Fuller CA, Postava-Davignon M (2014) Termites like it hot and humid: the ability of 811 arboreal tropical termites to mediate their nest environment against ambient $812 \quad$ conditions. Ecol Entomol 39:253-262

814 Ganapaty S, Thomas PS, Fotso S, Laatsch H (2004) Antitermitic quinones from 815 Diospyros sylvatica. Phytochemistry 65:1265-1271

816

817 Gazal V, Bailez O, Viana-Bailez AM (2014) Mechanism of trail following by the 818 arboreal termite Nasutitermes corniger (Isoptera: Termitidae). Zool Sci 31:1-5

Gazal V, Bailez O, Viana-Bailez AM (2010) Wood preference of Nasutitermes corniger (Isoptera: Termitidae). Sociobiology 55:433-443 Decayed wood affecting the attraction of the pest arboreum termite Nasutitermes corniger (Isoptera: Termitidae) to resource foods. Sociobiology 59:287-295 Behavioral responses of the arboreal termite Nasutitermes corniger (Isoptera: Termitidae) to wood extracts. Wood Sci Technol 48:581-590 
834 Grewal P, Georgis R (1999) Entomopathogenic nematodes. In: Biopesticides: Use and Delivery. Springer, pp. 271-299

836

837 Gush TJ, Bentley BL, Prestwich GD, Thorne BL (1985) Chemical variation in defensive secretions of four species of Nasutitermes. Biochem Syst Ecol 13:329-336

839

840

Hagen HA (1858) Specielle Monographie der Termiten. Linnea Entomologica 12:4-342

841

842

Hall P, Traniello JF (1985) Behavioral bioassays of termite trail pheromones. J Chem Ecol 11:1503-1513

844

Hartke TR, Rosengaus RB (2013) Costs of pleometrosis in a polygamous termite. P Roy Soc Lond B Bio 280:1756

847

Harun J, Labosky Jr P (1985) Antitermitic and antifungal properties of selected bark extractives. Wood Fiber Sci 17:327-335

850

He S, Ivanova N, Kirton E, Allgaier M, Bergin C, Scheffrahn RH, Kyrpides NC, Warnecke F, Tringe SG, Hugenholtz P (2013) Comparative metagenomic and metatranscriptomic analysis of hindgut paunch microbiota in wood-and dung-feeding higher termites. PloS one 8:e61126

855

856 Himmi SK, Tarmadi D, Ismayati M, Yusuf S (2013) Bioefficacy performance of neem-based formulation on wood protection and soil barrier against subterranean 
termite, Coptotermes gestroi Wasmann (Isoptera: Rhinotermitidae). Procedia Environmental Sciences 17:135-141

Holmgren N (1909) Termitenstudien 1. Anatomische untersuchungen. Kungliga Svenska Vetenskapsakademiens Handlingar 44:1-215

Holmgren N (1910) Versuch einer Monographie der amerikanische Eutermes - Arten. Jahrbuch der Hamburgischen Wissenschaftlichen Anstalten 27:171-325

Holmgren N (1912) Termitenstudien 3. Systematik der Termiten. Die Familie Metatermitidae. Kungliga Svenska Vetenskapsakademiens Handlingar 48:1-166

Houël E, Gonzalez, G, Bessière J-M, Odonne G, Eparvier V, Deharo E, Stien D (2015) Therapeutic switching: from antidermatophytic essential oils to new leishmanicidal products. Mem I Oswaldo Cruz 110:106-113

Inward DJG, Vogler AP, Eggleton P (2007) A comprehensive phylogenetic analysis of termites (Isoptera) illuminates key aspects of their evolutionary biology. Mol Phylogenet Evol 44: 953-967

ITIS (2014) from the Integrated Taxonomic Information System on-line database, http://www.itis.gov. [Accessed May, 7, 2014]

Ivbijaro MF, Umeh V, Mutsaers H (1993) Laboratory toxicity of the crude extracts of Piper guineense Schum and Thonn, Azadirachta indica A. Juss and Parkia 
Jaffe K, Ramos C, Issa S (1995) Trophic interactions between ants and termites that share common nests. Ann Entomol Soc Am 88:328-333

Jones R (1979) Expansion of the nest of Nasutitermes costalis. Insectes Sociaux 26:322-

Jones R (1980) Gallery construction by Nasutitermes costalis: Polyethism and the behavior of individuals. Insect Soc 27:5-28

894

Kampe A, Magel E (2013) New insights into heartwood and heartwood formation. In: Cellular Aspects of Wood Formation. Springer Berlin Heidelberg, pp 71-95

Krishna K, Grimaldi DA, Krishna V, Engel MS (2013) Treatise on the Isoptera of the World. B Am Mus Nat Hist 377: 1-2704

900 actinobacterial community structure and diversity associated with the wood-feeding termite species, Nasutitermes corniger (Motschulsky) described by nested PCRDGGE analysis. Insect Soc 56:269-276

905 (Isoptera:Termitidae) in a Panamanian mangrove forest. J Anim Ecol 53:705-714 
909 Lima VLS, Bailez OE, Viana-Bailez AM (2013) Caste polymorphism of apterous line of the Neotropical termite Nasutitermes corniger (Motschulsky) (Isoptera, Termitidae). Rev Bras Entomol 57:309-312

912

913 Lima T de A, Pontual EV, Dornelles LP, Amorim PK, Sá RA, Coelho LCBB, Napoleão 914 TH, Paiva PMG (2014) Digestive enzymes from workers and soldiers of termite Nasutitermes corniger. Comp Biochem Physiol Part B: Biochem Mol Biol 176:1-8

916

917 Linnaeus C (1758) Systema Naturae. 10th ed. Laurentii Salvii, Holmiae

Maistrello L, Henderson G, Laine RA (2003) Comparative effects of vetiver oil, nootkatone and disodium octaborate tetrahydrate on Coptotermes formosanus and its symbiotic fauna. Pest Manage Sci 59:58-68

922

Maistrello L, Henderson G, Laine RA (2001) Efficacy of vetiver oil and nootkatone as soil barriers against Formosan subterranean termite (Isoptera: Rhinotermitidae). J Econ Entomol 94:1532-1537

926

927 Mathews AGA (1977) Studies on Termites from the Mato Grosso State, Brazil. Academia Brasileira de Ciências, Rio de Janeiro 
McMahan EA (1970) Polyethism in workers of Nasutitermes costalis (Holmgren). Insect Soc 17:113-120

Meikle WG, Mercadier G, Rosengaus RB, Kirk AA, Derouané F, Quimby PC (2005) Evaluation of an entomopathogenic fungus, Paecilomyces fumosoroseus (Wize) Brown and Smith (Deuteromycota: Hyphomycetes) obtained from Formosan subterranean termites (Isop., Rhinotermitidae). J Appl Entomol 129:315-322

Mello AP, Costa BG, Santos AC, Silva AMB, Bezerra-Gusmão MA (2014) Termite infestation in historical buildings and residences in the semiarid region of Brazil. Sociobiology 61:318-323

Mikaelyan A, Strassert JFH, Tokuda G, Brune A (2014) The fibre-associated cellulolytic bacterial community in the hindgut of wood-feeding higher termites (Nasutitermes spp.). Environ Microbiol 16:2711-2722

Miura T, Roisin Y, Matsumoto T (2000) Molecular phylogeny and biogeography of the Nasute termite genus Nasutitermes (Isoptera: Termitidae) in the Pacific Tropics. Mol Phylogenet Evol 17:1-10

Miyata R, Noda N, Tamaki H, Kinjyo K, Aoyagi H, Uchiyama H, Tanaka H (2007) Influence of feed components on symbiotic bacterial community structure in the gut of the wood-feeding higher termite Nasutitermes takasagoensis. Biosci Biotech Bioch $71: 1244-1251$ 
Mo J, Wang Z, Song X, Guo J, Cao X, Cheng J (2006) Effects of sublethal concentration of ivermectin on behaviour of Coptotermes formasanus. Sociobiology 47:687-696

Müller F (1873) Beiträge zur Kenntniss der Termiten I-II. Jenaische Zeitschrift für Medizin und Naturwissenschaft 7:333-358

Napoleão TH, Gomes FS, Lima TA, Santos ND, Sá RA, Albuquerque AC, Coelho LC, Paiva PM (2011) Termiticidal activity of lectins from Myracrodruon urundeuva against Nasutitermes corniger and its mechanisms. Int Biodeter Biodegr 65:52-59

Nirma C, Eparvier V, Stien D (2013) Antifungal agents from Pseudallescheria boydii SNB-CN73 isolated from a Nasutitermes sp. termite. J Nat Prod 76:988-991

Nirma C, Rodrigues AM, Basset C, Chevolot L, Girod R, Moretti C, Stien D, Dusfour I, Eparvier V (2012) Larvicidal activity of isoflavonoids from Muellera frutescens extracts against Aedes aegypti. Nat Prod Comm 7:1319-1322

Paes JB, de Souza AD, de Lima CR, de Medeiros Neto PN (2010) Efficiency of neem and castor oil plant oils against xylophogous termites under forced food assay. Cerne $16: 105-113$

Paiva PM, Santana G, Souza IF, Albuquerque LP, Agra-Neto AC, Albuquerque AC, Luz LA, Napoleão TH, Coelho LC (2011) Effect of lectins from Opuntia ficus indica cladodes and Moringa oleifera seeds on survival of Nasutitermes corniger. Int Biodeter Biodegr 65:982-989 
984 Peres Filho O, Dorval A, Duda MJ, Moura RG (2006) Nasutitermes sp. (Isoptera, Termitidae) response to extract from four brazilian woods. Scientia Florestalis 71:51-

Pluke RWH, Permaul D, Leibee GL (1999) Integrated pest management and the use of botanicals in Guyana. Bib. Orton IICA/CATIE

990

Postava-Davignon MA (2010) Evolution and ecology of termite nesting behavior and its impact on disease susceptibility. Biology Dissertations http://hdl.handle.net/2047/d20000126

994

Prestwich G and Bentley BL (1981) Nitrogen fixation by intact colonies of the termite 996 Nasutitermes corniger. Oecologia 49:249-251

Ragon KW, Nicholas DD, Schultz TP (2008) Termite-resistant heartwood: The effect of the non-biocidal antioxidant properties of the extractives (Isoptera: Rhinotermitidae). Sociobiology 52:47-54

Rodrigues A (2010) Valorisation des extractibles responsables de la durabilité naturelle des bois exploités de Guyane Française. PhD Thesis, Université des Antilles et de la Guyane and Université fédérale de Brasilia 
Rodrigues A, Amusant N, Beauchêne J, Eparvier V, Leménager N, Baudassé C, Espindola LS, Stien D (2011) The termiticidal activity of Sextonia rubra (Mez) van der Werff (Lauraceae) extract and its active constituent rubrynolide. Pest Manage Sci

1011 $67: 1420-1423$

1012

1013

Rodrigues AMS, Theodoro PNET, Eparvier V, Basset C, Silva MRR, Beauchêne J, Espindola LS, Stien D (2010) Search for antifungal compounds from the wood of durable tropical tress. J Nat Prod 73:1706-1707

1016

Roisin Y, Everaerts C, Pasteels J, Bonnard O (1990) Caste-dependent reactions to soldier defensive secretion and chiral alarm/recruitment pheromone in Nasutitermes princeps. J Chem Ecol 16:2865-2875

1020

Rojas MG and Morales-Ramos JA (2001) Bait matrix delivery of chitin synthesis inhibitors to the Formosan subterranean termite (Isoptera: Rhinotermitidae). J Econ

Rosengaus RB, Lefebvre ML, Traniello JF (2000) Inhibition of fungal spore germination by Nasutitermes: evidence for a possible antiseptic role of soldier defensive secretions. J Chem Ecol 26:21-39 N Eds, Biology of Termites: A Modern Synthesis. Springer Netherlands, Dordrecht, pp. $499-517$ 
Roy V, Constantino R, Chassany V, Giusti Miller S, Diouf M, Mora P, Harry M (2014) Species delimitation and phylogeny in the genus Nasutitermes (Termitidae: Nasutitermitinae) in French Guiana. Mol Ecol 23:902-920

Sá RA, Argolo AC, Napoleão TH, Gomes FS, Santos ND, Melo CM, Albuquerque AC, Xavier HS, Coelho LC, Bieber LW (2009) Antioxidant, Fusarium growth inhibition and Nasutitermes corniger repellent activities of secondary metabolites from Myracrodruon urundeuva heartwood. Int Biodeter Biodegr 63:470-477

Sá RA, Napoleão TH, Santos ND, Gomes FS, Albuquerque AC, Xavier HS, Coelho LC, Bieber LW, Paiva PM (2008) Induction of mortality on Nasutitermes corniger (Isoptera, Termitidae) by Myracrodruon urundeuva heartwood lectin. Int Biodeter Biodegr 62:460-464

Salas-Acuña B (2012) Posibilidades de control de Nasutitermes corniger utilizando el hongo entomopatógeno Metarhizium sp. Revista Forestal Mesoamericana Kurú 2:16

Santana AL, Maranhão CA, Santos JC, Cunha FM, Conceição GM, Bieber LW, Nascimento MS (2010) Antitermitic activity of extractives from three Brazilian hardwoods against Nasutitermes corniger. Int Biodeter Biodegr 64:7-12

Santos PP, Vasconcellos A, Jahyny B, Delabie JHC (2010) Ant fauna (Hymenoptera, Formicidae) associated to arboreal nests of Nasutitermes spp. (Isoptera, Termitidae) in a cacao plantation in southeastern Bahia, Brazil. Rev Bras Entomol 54:450-454 
Scharf ME (2015) Termites as targets and models for biotechnology. Annu Rev Entomol 60:77-102

1060

Scheffrahn RH, Scherer CW (2013) Efficacy of Altriset ${ }^{\circledR}$ on the tropical arboreal termite, Nasutitermes corniger (Isoptera: Termitidae: Nasutitermitinae). Fla Entomol

1064

Scheffrahn RH, Cabrera BJ, Kern Jr WH, Su N-Y (2002) Nasutitermes costalis (Isoptera: Termitidae) in Florida: first record of a non-endemic establishment by a higher termite. Fla Entomol 85:273-275

1068

Scheffrahn RH, Hochmair HH, Kern Jr WH, Warner J, Krecek J, Maharajh B, Cabrera BJ, Hickman R (2014) Targeted elimination of the exotic termite, Nasutitermes corniger (Isoptera: Termitidae: Nasutitermitinae), from infested tracts in southeastern Florida. Int J Pest Manage 60:9-21

1073

Scheffrahn RH, Krecek J, Szalanski AL, Austin JW (2005a) Synonymy of neotropical arboreal termites Nasutitermes corniger and $N$. costalis (Isoptera: Termitidae: Nasutitermitinae), with evidence from morphology, genetics, and biogeography. Ann

1078

Scheffrahn RH, Krecek J, Szalanski AL, Austin JW, Roisin Y (2005b) Synonymy of two arboreal termites (Isoptera: Termitidae: Nasutitermitinae): Nasutitermes corniger from the Neotropics and N. polygynus from New Guinea. Fla Entomol 88:28-33 
Scheffrahn RH, Su N-Y, Diehl B (1990) Native, introduced, and structure-infesting termites of the Turks and Caicos Islands, BWI (Isoptera: Kalotermitidae, Rhinotermitidae, Termitidae). Fla Entomol 73:622-627

Schultz TP, Nicholas DD, McIntyre CR (2008) Recent patents and developments in biocidal wood protection systems for exterior applications. Recent Patents on Materials Science 1:128-134

Schultz TP, Nicholas DD, Preston AF (2007) A brief review of the past, present and future of wood preservation. Pest Manage Sci 63:784-788

Serit M, Ishida M, Hagiwara N, Kim M, Yamamoto T and Takahashi S (1992) Meliaceae and rutaceae limonoids as termite antifeedants evaluated using Reticulitermes speratus kolbe (Isoptera: Rhinotermitidae). J Chem Ecol 18:593-603

Sharma S, Vasudevan P, Madan M (1991) Insecticidal value of castor (Ricinus cummunis) against termites. Int Biodeter Biodegr 27:249-254

Sharma S, Verma M, Prasad R, Yadav D (2011) Efficacy of non-edible oil seedcakes against termite (Odontotermes obesus). J Sci Ind Res 70:1037-1041

Shelton TG, Grace K (2003) Termite Physiology in relation to wood degradation and termite control. In: Goodell B, Nicholas DD, Schultz TP, Wood deterioration and preservation: advances in our changing world, San Diego, California, pp. 242-250 
Siderhurst MS, James DM, Blunt TD, Bjostad LB (2005) Antimicrobial activity of the termite (Isoptera) alkaloid norharmane against the entomopathogenic fungus Metarhizium anisopliae. Sociobiology 46:563-577

Sillam-Dussès D, Sémon E, Robert A, Cancello E, Lenz M, Valterova I, Bordereau C (2010) Identification of multi component trail pheromones in the most evolutionarily derived termites, the Nasutitermitinae (Termitidae). Biol J Linn Soc 99:20-27

1115

Silva MD, Sá RA, Napoleão TH, Gomes FS, Santos ND, Albuquerque AC, Xavier HS, Paiva PM, Correia MT, Coelho LC (2009) Purified Cladonia verticillaris lichen lectin: Insecticidal activity on Nasutitermes corniger (Isoptera: Termitidae). Int Biodeter Biodegr 63:334-340

Silvestri, F. 1903. Contribuzione alla conoscenza dei Termitidi e Termitofili dell'America Meridionale. Redia 1: 1-234

Smeathman, H. 1781. Some account of the termites, which are found in Africa and other hot climates. Philos Trans R Soc Lond 71:139-192 Miscellaneous Collections 112:1-490 MD, Coelho LC (2011) A new Bauhinia monandra galactose-specific lectin purified 
in milligram quantities from secondary roots with antifungal and termiticidal activities. Int Biodeter Biodegr 65:696-702

Stuart AM (1963) Origin of the trail in the termites Nasutitermes corniger (Motschulsky) and Zootermopsis nevadensis (Hagen), Isoptera. Physiol Zool 36:69-84

Su N-Y and Scheffrahn RH (1998) A review of subterranean termite control practices and prospects for integrated pest management programs. Integrated Pest Management Review 3:1-13

Su N-Y and Scheffrahn RH (1993) Laboratory evaluation of two chitin synthesis inhibitors, hexaflumuron and diflubenzuron, as bait toxicants against the Formosan subterranean termite (Isoptera: Rhinotermitidae). J Econ Entomol 86:1453-1457

Tahiri A, Amissa adima A, Adje F, Amusant N (2011) Effet pesticide et screening des extraits de Azadirachta indica (A.) Juss. sur le termite Macrotermes bellicosus Rambur. Bois For Trop 310:79-88 atmospheric nitrogen. Naturwissenschaften 81:229-231 a review. Wood Fiber Sci 34:587-611 
Thorne BL (1983) Alate production and sex ratio in colonies of the Neotropical termite Nasutitermes corniger (Isoptera; Termitidae). Oecologia 58:103-109

Thorne BL (1980) Differences in nest architecture between the neotropical arboreal termites, Nasutitermes corniger and Nasutitermes ephratae (Isoptera: Termitidae). Psyche 87:235-244

1162

Thorne BL (1984) Polygyny in the Neotropical termite Nasutitermes corniger: life history consequences of queen mutualism. Behav Ecol Sociobiol 14:117-136

Thorne BL, Collins MS, Bjorndal KA (1996) Architecture and nutrient analysis of arboreal carton nests of two neotropical Nasutitermes species (Isoptera: Termitidae), with notes on embedded nodules. Fla Entomol 79:27

Traniello JF, Busher C (1985) Chemical regulation of polyethism during foraging in the neotropical termite Nasutitermes costalis. J Chem Ecol 11:319-332

Traniello JF (1981) Enemy deterrence in the recruitment strategy of a termite: soldierorganized foraging in Nasutitermes costalis. Proc Nat Acad Sci 78:1976-1979

UNEP/FAO (2000) Global IPM Facility Expert Group on Termite Biology and Management. Finding alternatives to persistent organic pollutants (POPs) for termite management.http://www.unep.org/chemicalsandwaste/Portals/9/Pesticides/Alternative 
Vasconcellos A and Moura FMDS (2010) Wood litter consumption by three species of Nasutitermes termites in an area of the Atlantic Coastal Forest in Northeastern Brazil. J Insect Sci 10:72

Verma M, Sharma S, Prasad R (2009) Biological alternatives for termite control: a review. Int Biodeter Biodegr 63:959-972

1187

Warnecke F, Luginbühl P, Ivanova N, Ghassemian M, Richardson TH, Stege JT, Cayouette M, McHardy AC, Djordjevic G, Aboushadi N, Sorek R, Tringe SG, Podar M, Martin HG, Kunin V, Dalevi D, Madejska J, Kirton E, Platt D, Szeto E, Salamov A, Barry K, Mikhailova N, Kyrpides NC, Matson EG, Ottesen EA, Zhang X, Hernandez M, Murillo C, Acosta LG, Rigoutsos I, Tamayo G, Green BD, Chang B, Rubin EM, Mathur EJ, Robertson DE, Hugenholtz P, Leadbetter JR (2007) Metagenomic and functional analysis of hindgut microbiota of a wood-feeding higher termite. Nature 450:560-565

YunLing K, GuanJun C, ShuAng Z, TianYong Z, ChunXiao W, WeiJin T (2009) Bioactivities of azadirachtin against Coptotermes formosanus (Isoptera: Rhinotermitidae). Sociobiology 53:677-685 invertebrates. Part 1: Antibacterial trinervitadienes from the termite Nasutitermes triodiae. Tetrahedron 60:10753-10759 
Figure 1: Cumulative number of valid species of Nasutitermes since 1758.

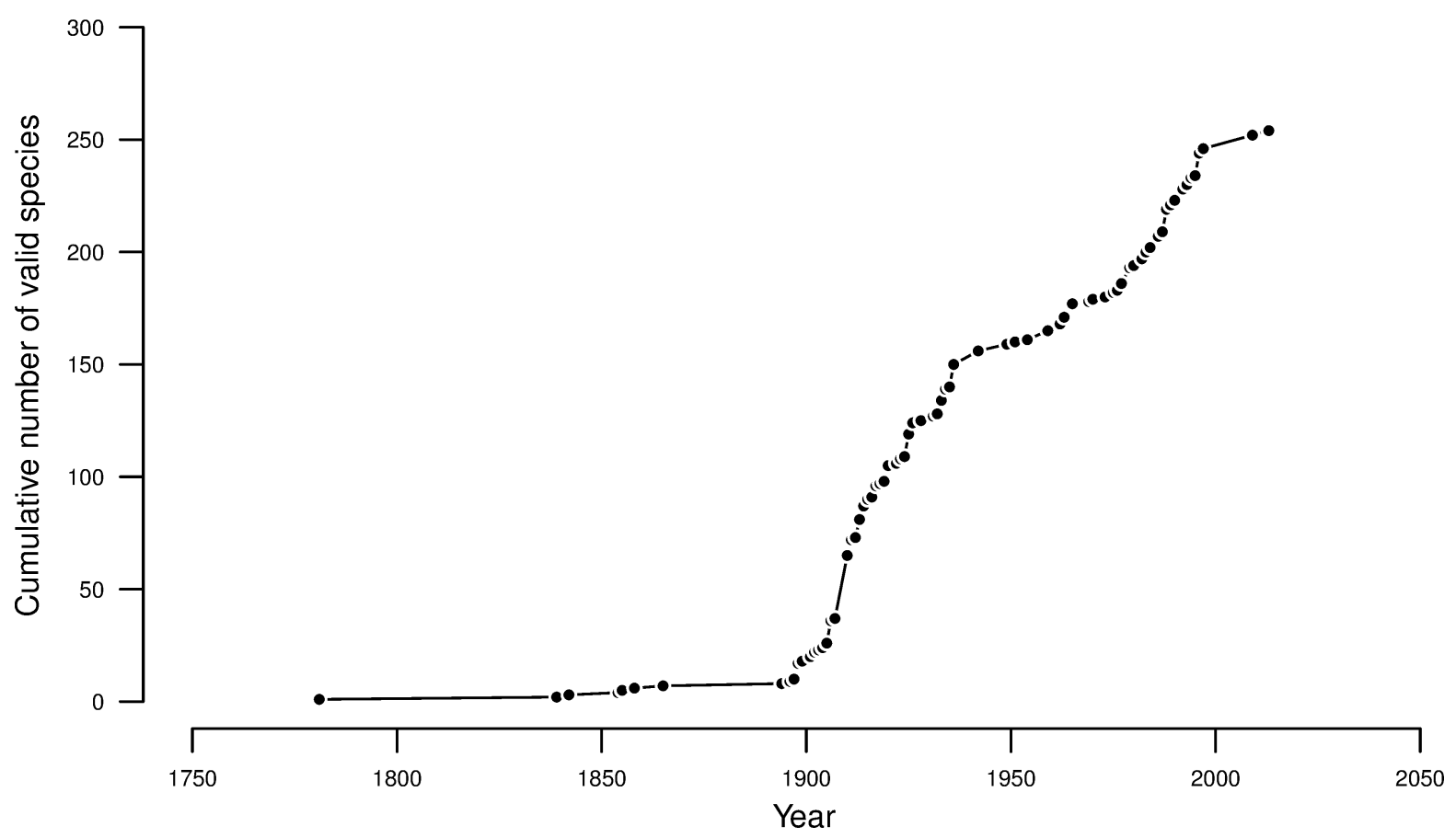


Figure 2: Geographical distribution of Nasutitermes corniger. This termite is native of Central and South America and the Caribbean islands, and is invasive in the Bahamas, Florida and New Guinea (according to Scheffrahn et al. and Evans et al.). ${ }^{7,9}$

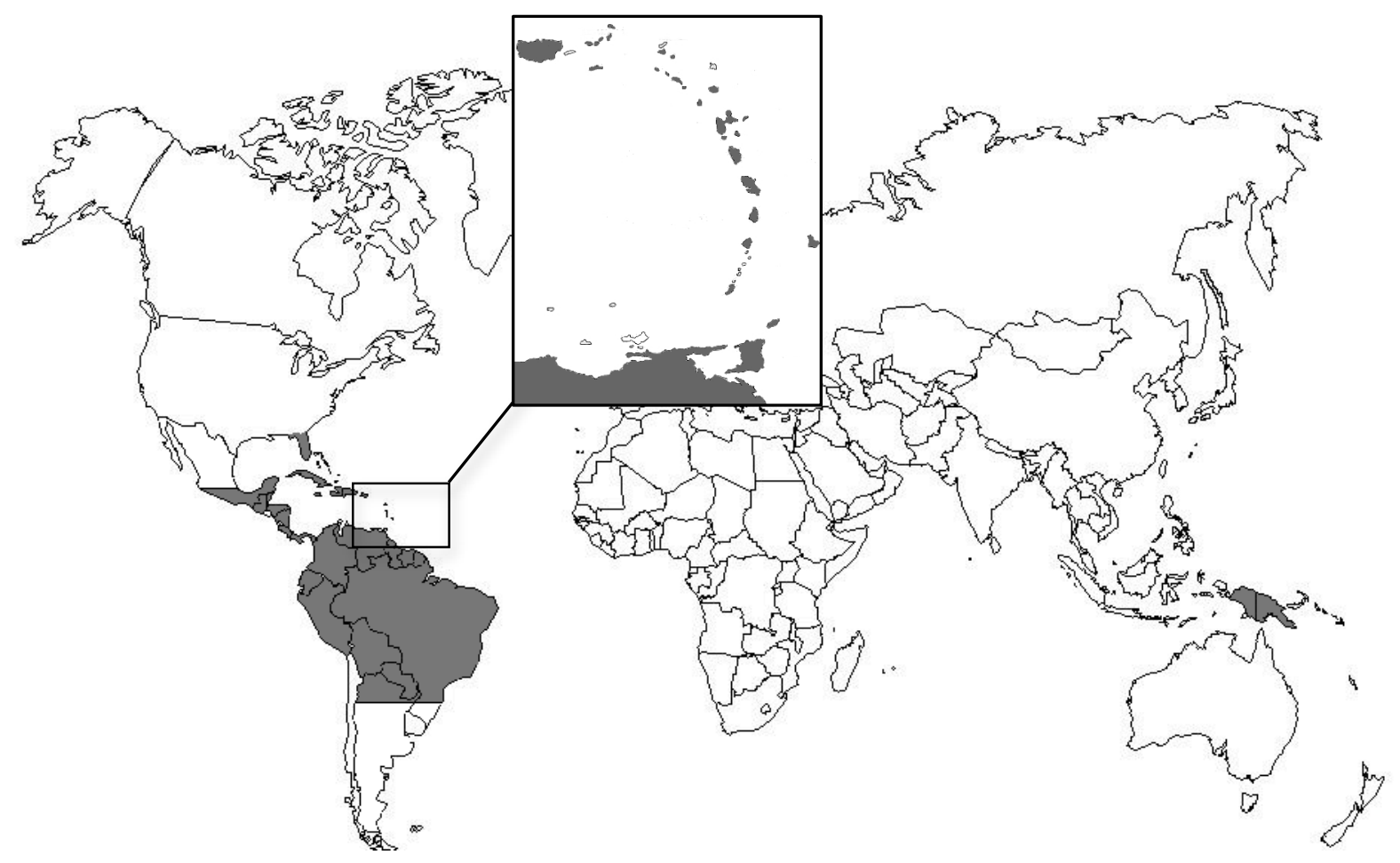


Apterous line GP
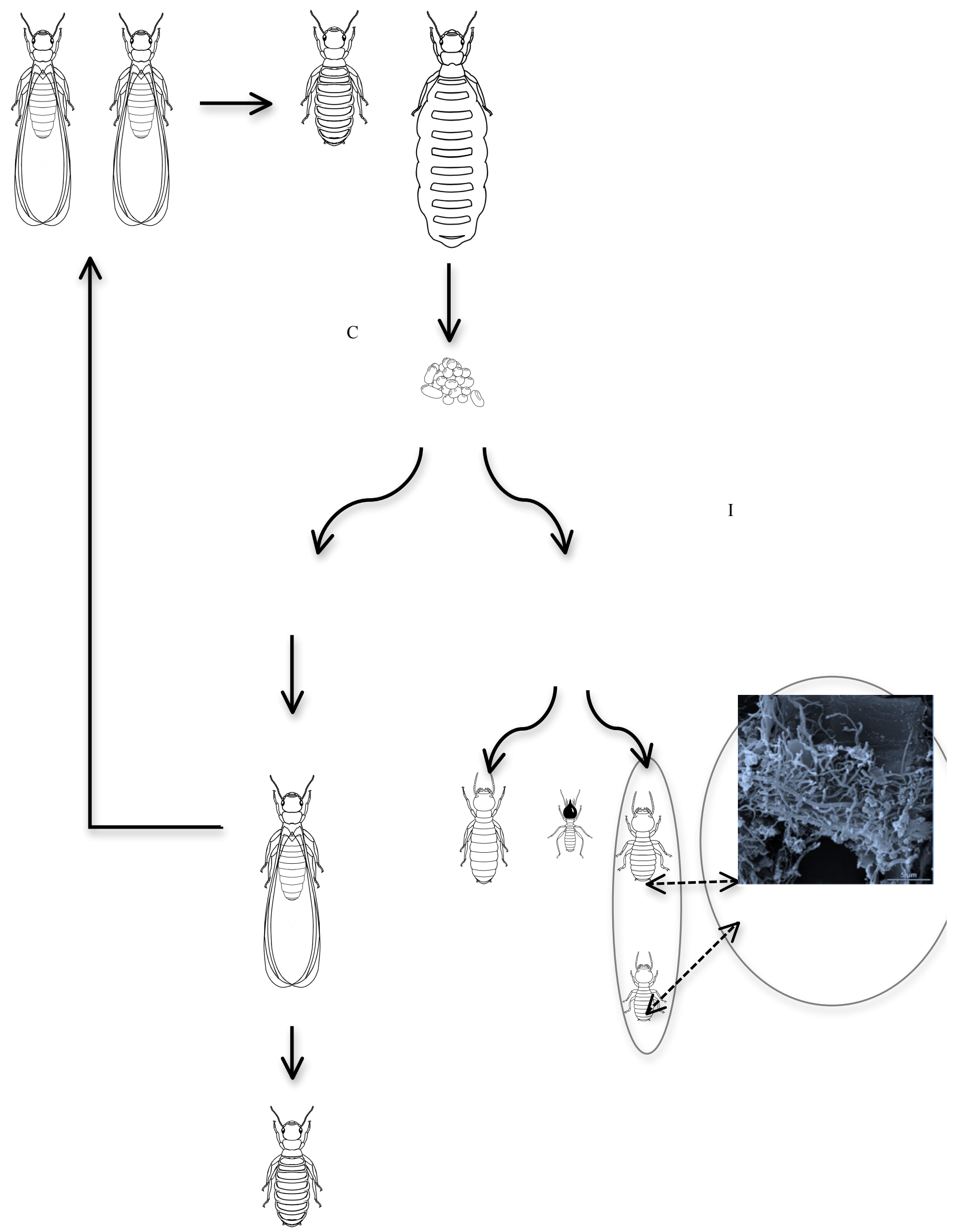

Figure 3: Nasutitermes corniger's colony with the king (A), queen (B), eggs (C), alate (D), adultoid (E), ergatoid (F), large (G1) and small (G2) workers, soldier (H), and gut's microbiome (photo according to Mikaelyan et al. 2014) (I). 
Dotted arrows indicate symbiotic relationships. Gray circles indicate targets of all pest management strategies found in the literature. 
Figure 4: Soldier (left) and major worker (right) of Nasutitermes corniger, same magnification. C) Copyright 2016 R. Constantino.
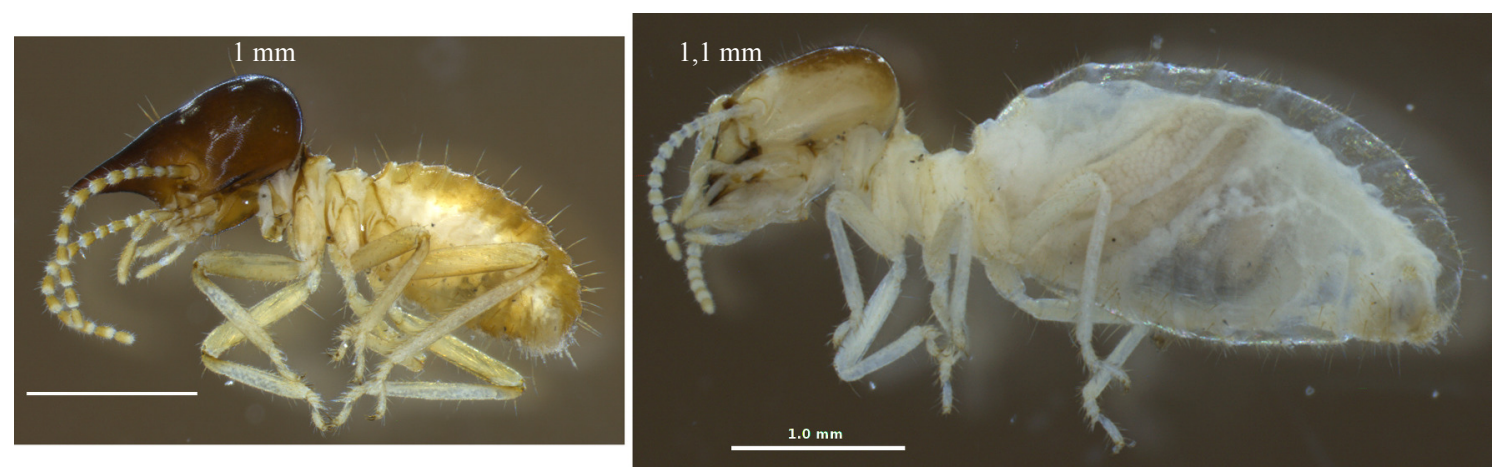
Figure 5: Arboreal nest of Nasutitermes corniger on a cacao tree. C Copyright 2016 R. Constantino.

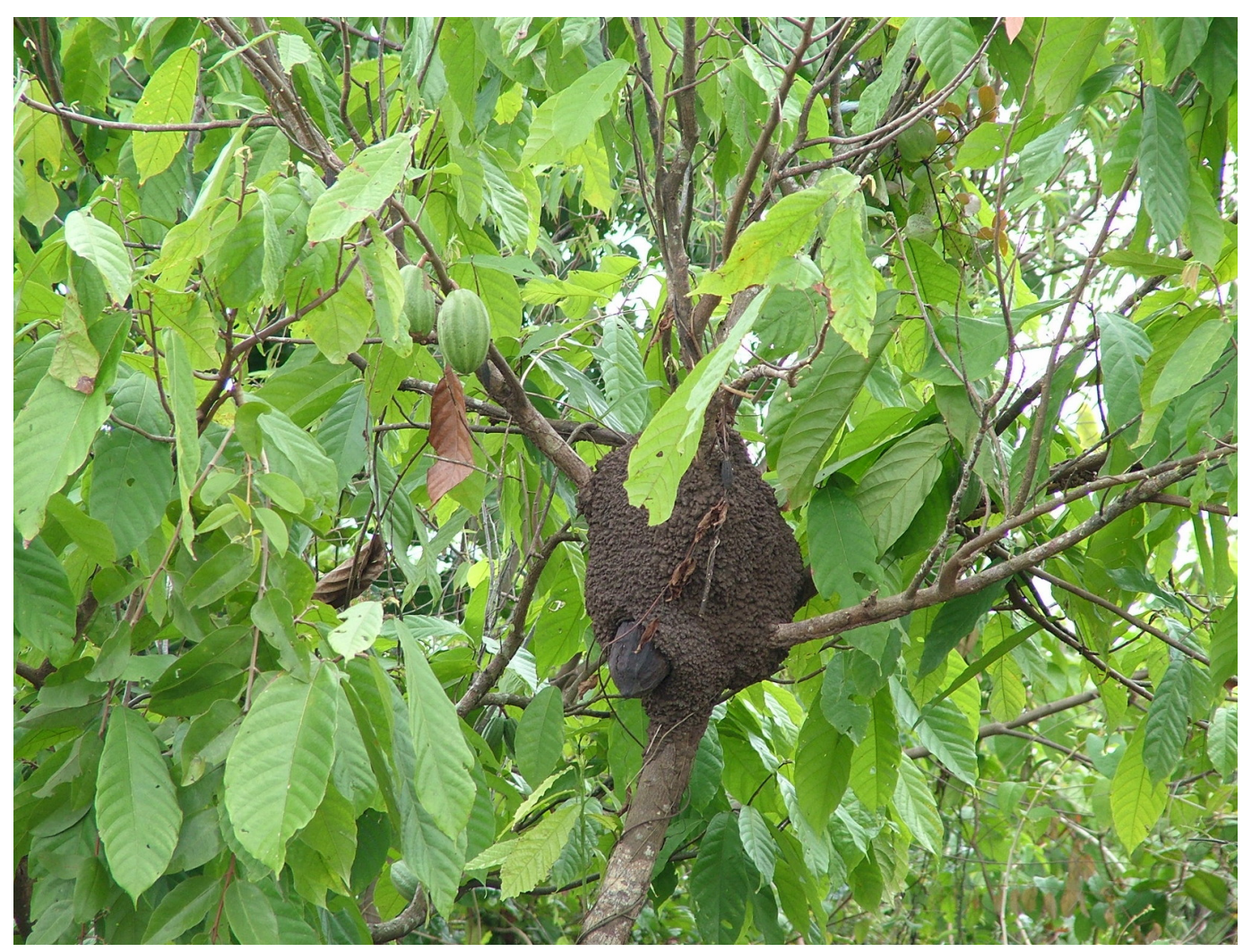


Table 1: Examples of the synthetic chemical products used for termite management.

\begin{tabular}{|c|c|c|}
\hline Classes & Active compounds & References \\
\hline Arsenic derivatives & $\begin{array}{l}\text { Chromated copper } \\
\text { arsenate (CCA) } \\
\text { Arsenic trioxide } \\
\text { Calcium arsenate }\end{array}$ & $\begin{array}{l}\text { Verma et al. 2009; UNEP } \\
\text { 2000; Santana et al. } 2010\end{array}$ \\
\hline Copper derivatives & $\begin{array}{l}\text { Alkaline copper quat } \\
\text { (ACQ) } \\
\text { Copper azole } \\
\text { Copper naphthenate }\end{array}$ & $\begin{array}{l}\text { UNEP 2000; Schultz et al. } \\
2007\end{array}$ \\
\hline Zinc derivatives & Zinc napthenate & $\begin{array}{l}\text { UNEP 2000; Schultz et al. } \\
2007\end{array}$ \\
\hline Borate formulations & $\begin{array}{l}\text { Disodium octaborate } \\
\text { tetrahydrate (DOT) }\end{array}$ & $\begin{array}{l}\text { UNEP 2000; Schultz et al. } \\
\text { 2007; Clausen and Yang } \\
2007\end{array}$ \\
\hline Pyrethroids & Permethrin & $\begin{array}{l}\text { UNEP 2000; Schultz et al. } \\
2007\end{array}$ \\
\hline Neonicotinoids & $\begin{array}{l}\text { Imidacloprid } \\
\text { Thiamethoxan }\end{array}$ & $\begin{array}{l}\text { Schultz et al. 2007; } \\
\text { Scheffrahn et al. } 2014\end{array}$ \\
\hline Phenylpyrazoles & $\begin{array}{l}\text { Fipronil, } \\
\text { Chlorfenapyr }\end{array}$ & $\begin{array}{l}\text { Verma et al. 2009; UNEP } \\
\text { 2000; Scheffrahn et al. } \\
\text { 2014, Santana et al. } 2010\end{array}$ \\
\hline Pyrethroid ethers & Silafluofen & $\begin{array}{l}\text { Verma et al. 2009; UNEP } \\
\text { 2000; Santana et al. } 2010\end{array}$ \\
\hline Organophosphate compounds & $\begin{array}{l}\text { Chlorpyrifos } \\
\text { Fenitrothion } \\
\text { Phenthoate } \\
\text { Triazophos }\end{array}$ & $\begin{array}{l}\text { Verma et al. 2009; UNEP } \\
\text { 2000; Santana et al. } 2010\end{array}$ \\
\hline Organochlorate compounds & Chlorothalonil & $\begin{array}{l}\text { Verma et al. 2009; UNEP } \\
\text { 2000; Santana et al. } 2010\end{array}$ \\
\hline Benzoylureas & $\begin{array}{l}\text { Chlorfluazuron } \\
\text { Diflubenzuron } \\
\text { Hexaflumuron } \\
\text { Triflumuron }\end{array}$ & $\begin{array}{l}\text { Verma et al. 2009; UNEP } \\
\text { 2000; Santana et al. } 2010\end{array}$ \\
\hline Anthralinic diamides & Chlorantraniliprole & $\begin{array}{l}\text { Verma et al. 2009; UNEP } \\
\text { 2000; Santana et al. 2010; } \\
\text { Scheffrahn and Scherer } \\
2013\end{array}$ \\
\hline Aminohydrazones & Hydramethylnon & $\begin{array}{l}\text { Verma et al. 2009; UNEP } \\
\text { 2000; Santana et al. } 2010\end{array}$ \\
\hline Spinosoids & Spinosad & $\begin{array}{l}\text { Verma et al. 2009; UNEP } \\
\text { 2000; Santana et al. } 2010\end{array}$ \\
\hline Sulfonamides & Sulfluramid & $\begin{array}{l}\text { Verma et al. 2009; UNEP } \\
\text { 2000; Santana et al. } 2010\end{array}$ \\
\hline Organic and inorganic gas & $\begin{array}{l}\text { Carbon dioxide } \\
\text { Methyl bromide } \\
\text { Phosphine } \\
\text { Sulfuryl fluoride }\end{array}$ & $\begin{array}{l}\text { Verma et al. 2009; UNEP } \\
\text { 2000; Santana et al. 2010; } \\
\text { Scheffrahn et al. } 2014\end{array}$ \\
\hline
\end{tabular}


Table 2: Sustainable management with antitermitic and antimicrobial botanicals and with entomopathogens.

\begin{tabular}{|c|c|c|c|c|}
\hline Termite & $\begin{array}{l}\text { Plant (Family)/part of } \\
\text { plant } \\
\text { or Entomopathogens } \\
\text { (Family) }\end{array}$ & Activity & $\begin{array}{l}\text { Active extracts / } \\
\text { compounds }\end{array}$ & References \\
\hline \multicolumn{5}{|c|}{ Antitermitic botanicals } \\
\hline N. corniger & $\begin{array}{l}\text { Diospyros dichroa Sandw. } \\
\text { (Ebenaceae) }\end{array}$ & $\begin{array}{l}\text { Repellent activity ( }> \\
90 \%) \text { at } 3.2 \mu \mathrm{g} / \mathrm{mm}^{2}(40 \\
\mathrm{mg} / \mathrm{ml})\end{array}$ & $\begin{array}{l}\text { Wood ethyl acetate } \\
\text { extract }\end{array}$ & $\begin{array}{l}\text { Pers. results based on } \\
\text { Ganapaty et al } 2004, \\
\text { Rodrigues } 2010 \text {, and } \\
\text { Boulogne et al } 2011 \\
\text { previous works }\end{array}$ \\
\hline N. corniger & $\begin{array}{l}\text { Lonchocarpus } \\
\text { chrysophyllus Kleinhoonte } \\
\text { (Fabaceae) }\end{array}$ & $\begin{array}{l}\text { Repellent activity ( }> \\
90 \%) \text { at } 3.2 \mu \mathrm{g} / \mathrm{mm}^{2}(40 \\
\mathrm{mg} / \mathrm{ml})\end{array}$ & $\begin{array}{l}\text { Bark ethyl acetate and } \\
\text { petroleum ether extracts }\end{array}$ & $\begin{array}{l}\text { Pers. results (Boulogne } \\
\text { et al. in prep) }\end{array}$ \\
\hline N. corniger & $\begin{array}{l}\text { Myracrodruon urundeuva } \\
\text { Allemão (Anacardiaceae)/ } \\
\text { heartwood }\end{array}$ & $\begin{array}{l}\text { No repellent activity } \\
\text { Contact toxicity } \\
\left(\mathrm{LC}_{50}=0.248 \mathrm{mg} / \mathrm{mL} \text { for }\right. \\
\text { workers and } 0.199 \\
\mathrm{mg} / \mathrm{mL} \text { for soldiers })\end{array}$ & Lectins & Sá et al. 2008 \\
\hline N. corniger & $\begin{array}{l}\text { M yracrodruon urundeuva } \\
\text { Allemão (Anacardiaceae)/ } \\
\text { heartwood and bark }\end{array}$ & $\begin{array}{l}\text { No contact toxicity } \\
\text { Repellent activity }\end{array}$ & $\begin{array}{l}\text { Crude methanolic } \\
\text { extract }\end{array}$ & Sá et al. 2009 \\
\hline N. corniger & $\begin{array}{l}\text { Anadenanthera colubrina } \\
\text { (Vell.) Brenan } \\
\text { (Fabaceae)/ heartwood }\end{array}$ & $\begin{array}{l}\text { Contact toxicity }(\mathrm{LC} 50= \\
7.3 \mathrm{mg} / \mathrm{mL} \text { for ethyl } \\
\text { acetate extract }, \mathrm{LC} 50 \\
=67.4 \mathrm{mg} / \mathrm{mL} \text { for } \\
\text { cyclohexane extract after } \\
4 \text { days })\end{array}$ & $\begin{array}{l}\text { Cyclohexane and ethyl } \\
\text { acetate extracts }\end{array}$ & Santana et al. 2010 \\
\hline N. corniger & $\begin{array}{l}\text { Hymenaea stigonocarpa } \\
\text { Hayne (Fabaceae)/ } \\
\text { heartwood }\end{array}$ & $\begin{array}{l}\text { Contact toxicity } \\
(\mathrm{LC} 50=11.9 \mathrm{mg} / \mathrm{mL} \text { after } \\
4 \text { days })\end{array}$ & Cyclohexane extract & Santana et al. 2010 \\
\hline N. corniger & $\begin{array}{l}\text { Bowdichia virgilioides } \\
\text { Kunth, (Fabaceae)/ } \\
\text { heartwood }\end{array}$ & $\begin{array}{l}\text { Contact toxicity } \\
\left(\mathrm{LC}_{50}=7.2 \mathrm{mg} / \mathrm{mL} \text { after } 4\right. \\
\text { days })\end{array}$ & Alkaloidal extract & Santana et al. 2010 \\
\hline N. corniger & $\begin{array}{l}\text { Bowdichia virgilioides } \\
\text { Kunth, (Fabaceae)/ } \\
\text { heartwood }\end{array}$ & $\begin{array}{l}\text { Toxic }\left(\mathrm{LC}_{50}=12.2 \mathrm{mg} / \mathrm{mL}\right. \\
\text { after } 4 \text { days) and repellent } \\
\text { activities }\end{array}$ & Cyclohexane extract & Santana et al. 2010 \\
\hline N. macrocephalus & $\begin{array}{l}\text { Sextonia rubra }(\mathrm{Mez}) \text { Van } \\
\text { der Werff (Lauraceae)/ } \\
\text { heartwood }\end{array}$ & $\begin{array}{l}\text { Contact toxicity } \\
\left(\mathrm{LC}_{100}<1.9 \mu \mathrm{g} / \mathrm{mm}^{2} \text { after }\right. \\
72 \mathrm{~h})\end{array}$ & $\begin{array}{l}\text { Ethyl-acetate extract/ } \\
\text { rubrynolide }\end{array}$ & Rodrigues et al. 2011 \\
\hline Nasutitermes sp & $\begin{array}{l}\text { Bagassa guianensis Aubl. } \\
\text { (Moraceae), } \\
\text { Erisma uncinatum Warm. } \\
\text { (Vochysiaceae), } \\
\text { Buchenavia parvifolia } \\
\text { Ducke (Combretaceae), } \\
\text { Dinizia excelsa Ducke } \\
\text { (Fabaceae) } \\
\text { Pouteria guianensis Aubl. } \\
\text { (Sapotaceae)/ wood }\end{array}$ & $\begin{array}{l}\text { Wood impregnation } \\
\text { conferred durability to } \\
\text { Cecropia sp. (Urticaceae) } \\
\text { and Simarouba amara } \\
\text { Aubl. (Simaroubaceae) } \\
\text { woods }\end{array}$ & & $\begin{array}{l}\text { Barbosa et al. } 2007 \text {; } \\
\text { Peres Filho et al. } 2006\end{array}$ \\
\hline N. macrocephalus & $\begin{array}{l}\text { Diospyros dichroa Sandw. } \\
\text { (Ebenaceae)/ wood }\end{array}$ & $\begin{array}{l}\text { Contact toxicity } \\
\left(\mathrm{LC}_{100}<1.9 \mu \mathrm{g} / \mathrm{mm}^{2} \text { and }\right. \\
\left.5.6 \mu \mathrm{g} / \mathrm{mm}^{2} \text { after } 72 \mathrm{~h}\right)\end{array}$ & $\begin{array}{l}\text { Methanolic extract and } \\
\text { Ethyl acetate extract. }\end{array}$ & $\begin{array}{l}\text { Harun and Labosky } \\
\text { 1985; Rodrigues } 2010\end{array}$ \\
\hline N. corniger & $\begin{array}{l}\text { Bauhinia monandra Kurz } \\
\text { (Fabaceae)/ roots }\end{array}$ & $\begin{array}{l}\text { Contact toxicity }\left(\mathrm{LC}_{50}=\right. \\
0.09 \mathrm{mg} / \mathrm{mL} \text { for workers } \\
\text { and } 0.395 \text { for soldiers } \\
\text { after } 12 \text { days })\end{array}$ & Lectins & Souza et al. 2011 \\
\hline N. corniger & $\begin{array}{l}\text { Opuntia ficus-indica (L.) } \\
\text { Mill. (Cactaceae)/ } \\
\text { cladodes }\end{array}$ & $\begin{array}{l}\text { Contact toxicity } \\
\left(\mathrm{LC}_{50}=0.116 \mathrm{mg} / \mathrm{mL} \text { for }\right. \\
\text { workers and } 1.5 \text { for } \\
\text { soldiers })\end{array}$ & Lectins & Paiva et al. 2011 \\
\hline N. corniger & $\begin{array}{l}\text { Moringa oleifera Lam. } \\
\text { (Moringaceae)/ seeds }\end{array}$ & $\begin{array}{l}\text { No repellent activity } \\
\text { Contact toxicity at } 1.0 \\
\text { and } 1.5 \mathrm{mg} / \mathrm{mL}\end{array}$ & Lectins & Paiva et al. 2011 \\
\hline N. corniger & $\begin{array}{l}\text { Myracrodruon urundeuva } \\
\text { Allemão (Anacardiaceae)/ } \\
\text { leaves }\end{array}$ & $\begin{array}{l}\text { Contact toxicity } \\
\left(\mathrm{LC}_{50}=0.374 \text { to } 0.974\right. \\
\mathrm{mg} / \mathrm{ml} \text { on workers and } \\
0.432 \text { to } 0.787 \mathrm{mg} / \mathrm{ml} \text { on } \\
\text { soldiers) }\end{array}$ & Lectins & Napoleão et al. 2011 \\
\hline N. corniger & Cladonia verticillaris & Contact toxicity & Lectins & Silva et al. 2009 \\
\hline
\end{tabular}




\begin{tabular}{|c|c|c|c|c|}
\hline & (Cladoniaceae) / lichen & $\begin{array}{l}\left(\mathrm{LC}_{50}=0.196 \mathrm{mg} / \mathrm{mL} \text { on }\right. \\
\text { workers and } 0.5 \mathrm{mg} / \mathrm{mL} \\
\text { on soldiers after } 10 \text { days })\end{array}$ & & \\
\hline N. corniger & $\begin{array}{l}\text { Microgramma vaccinifolia } \\
\text { (Langsd. \& Fisch.) Copel. } \\
\text { (Polypodiaceae)/ rhizome }\end{array}$ & $\begin{array}{l}\text { Contact toxicity } \\
\text { Ability to disrupt trypsin- } \\
\text { like protease, acid } \\
\text { phosphatase, and } \\
\text { cellulase activities in } \\
\text { termite's gut }\end{array}$ & Lectins & Lima et al. 2014 \\
\hline $\begin{array}{l}\text { Coptotermes } \\
\text { formosanus, } \\
\text { Coptotermes gestroi, } \\
\text { Reticulitermes speratus, } \\
\text { Macrotermes bellicosus, } \\
\text { Macrotermes } \\
\text { nigeriensis, } \\
\text { Odontotermes obesus, }\end{array}$ & $\begin{array}{l}\text { Azadirachta indica A. } \\
\text { Juss. (Meliaceae) } \\
\text { Ricinus communis L. } \\
\text { (Euphorbiaceae) }\end{array}$ & $\begin{array}{l}\text { Contact toxicity, } \\
\text { metabolic poison, } \\
\text { repellent or antifeedant } \\
\text { activities }\end{array}$ & & $\begin{array}{l}\text { Sharma et al. 1991; } \\
\text { Grace and Yates 1992; } \\
\text { Serit et al. 1992; } \\
\text { Ivbijaro et al. 1993; } \\
\text { Delate and Grace 1995; } \\
\text { Chuanchuan et al. } \\
\text { 1998; UNEP 2000; } \\
\text { Yunling et al. 2009; } \\
\text { Sharma et al. 2011; } \\
\text { Tahiri et al. 2011; } \\
\text { Himmi et al. 2013 }\end{array}$ \\
\hline \multicolumn{5}{|c|}{ Antimicrobial botanicals } \\
\hline N. corniger & $\begin{array}{l}\text { Myracrodruon urundeuva } \\
\text { Allemão (Anacardiaceae)/ } \\
\text { bark, heartwood and leaf }\end{array}$ & $\begin{array}{l}\text { Antibacterial activity on } \\
\text { gut's symbiotic bacteria } \\
\text { (MIC from } 62.5 \text { to } 250 \\
\mathrm{mg} / \mathrm{mL} \text { ) }\end{array}$ & Lectins & Napoleão et al. 2011 \\
\hline Microtermes obesi & $\begin{array}{l}\text { Withania somnifera (L.) } \\
\text { Dunal (Solanaceae), } \\
\text { Croton tiglium L. } \\
\text { (Euphorbiaceae) and } \\
\text { Hygrophila auriculata } \\
\text { Schumach.) Heine } \\
\text { (Acanthaceae) / seeds and } \\
\text { leaves }\end{array}$ & $\begin{array}{l}\text { Reduction of colonies } \\
\text { number of bacterial } \\
\text { symbionts }\end{array}$ & & Ahmed et al. 2006 \\
\hline $\begin{array}{l}\text { Coptotermes } \\
\text { formosanus }\end{array}$ & $\begin{array}{l}\text { Chrysopogon zizanioides } \\
\text { (L.) Roberty (syn.Vetiveria } \\
\text { zizanioides (L.) Nash) } \\
\text { (Poaceae) }\end{array}$ & $\begin{array}{l}\text { Reduction number of } \\
\text { hindgut flagellate species } \\
\text { (more specially } \\
\text { Pseudotrichonympha } \\
\text { grassii, an important } \\
\text { cellulolytic flagellate } \\
\text { protist) }\end{array}$ & Oil/ Nootkatone & $\begin{array}{l}\text { Maistrello et al. 2003; } \\
2011\end{array}$ \\
\hline $\begin{array}{l}\text { Coptotermes } \\
\text { formosanus }\end{array}$ & $\begin{array}{l}\text { Azadirachta indica A. } \\
\text { Juss. (Meliaceae) }\end{array}$ & $\begin{array}{l}\text { Reduction of population } \\
\text { of } P \text {. grassii and } \\
\text { Spirochaetes }\end{array}$ & Azadirachtin & Doolittle et al. 2007 \\
\hline \multicolumn{5}{|c|}{ Entomopatogens } \\
\hline Nasutitermes sp. & $\begin{array}{l}\text { Termitaria coronata } \\
\text { (Deuteromycetes, } \\
\text { Termitariales) }\end{array}$ & & & Ensaf et al. 2006 \\
\hline $\begin{array}{l}\text { N. corniger and } \\
\text { Nasutitermes sp. }\end{array}$ & Metarhizium sp & & & $\begin{array}{l}\text { Chouvenc et al. 2011; } \\
\text { Salas-Acuña } 2012\end{array}$ \\
\hline
\end{tabular}

